\title{
Consequences of Neutralization on the Proliferation and Cytoskeletal Organization of Chondrocytes on Chitosan-Based Matrices
}

\author{
Sandra E. Noriega and Anuradha Subramanian \\ Department of Chemical and Biomolecular Engineering, University of Nebraska, Lincoln, 207 Othmer Hall Lincoln, \\ NE 68588-0643, USA \\ Correspondence should be addressed to Anuradha Subramanian, asubramanian2@unl.edu
}

Received 2 February 2011; Revised 4 May 2011; Accepted 2 July 2011

Academic Editor: José das Neves

Copyright (C) 2011 S. E. Noriega and A. Subramanian. This is an open access article distributed under the Creative Commons Attribution License, which permits unrestricted use, distribution, and reproduction in any medium, provided the original work is properly cited.

\begin{abstract}
In tissue engineering strategies that seek to repair or regenerate native tissues, adhesion of cells to scaffolds or matrices is essential and has the potential to influence subsequent cellular events. Our focus in this paper is to better understand the impact of cellular seeding and adhesion in the context of cartilage tissue engineering. When scaffolds or surfaces are constructed from chitosan, the scaffolds must be first neutralized with sodium hydroxide and then washed copiously to render the surface, cell compatible. We seek to better understand the effect of surface pretreatment regimen on the cellular response to chitosan-based surfaces. In the present paper, sodium hydroxide concentration was varied between $0.1 \mathrm{M}$ and $0.5 \mathrm{M}$ and two different contacting times were studied: 10 minutes and 30 minutes. The different pretreatment conditions were noted to affect cell proliferation, morphology, and cytoskeletal distribution. An optimal set of experimental parameters were noted for improving cell growth on scaffolds.
\end{abstract}

\section{Introduction}

The successful cellular colonization of scaffolds for use in tissue engineering applications often relies on an important first step: cell seeding, where cells in suspension adhere to scaffolds or matrices [1]. Poor or inadequate cell adhesion often yields low starting cell densities that can result in lower cellular yields upon completion of the in vitro cell culture step. While in general, cellular adhesion is a critical step in most tissue engineering strategies that seek to repair or regenerate the native tissue, our focus in this study is to better understand the impact of cellular seeding and adhesion in the context of cartilage tissue engineering. Scaffold parameters that impact tissue engineering strategies include chemical $[2-5]$ and mechanical properties [6], geometry (2D [7] versus $3 \mathrm{D}[7,8]$; micro [9-11] versus nano [12]), environment, and morphology (pore size and pore shape) $[6,13]$.

Most materials that are used in the preparation of scaffolds for use in tissue engineering applications are either derived from natural origin (collagen, gelatin, chitosan, and agarose) or prepared from synthetic polymers (poly(lactic acid) (PLA), poly(L-lactic acid)-polyglycolic acid (PLLAPGA), poly( $\varepsilon$-caprolactone) (PCL), etc.) [14-16]. Cellular response to biomaterial interfaces is often directed by surface characteristics. For example, cell adhesion has been shown to be influenced by substrate chemistry, which partly modulates the pattern, conformation, and extent of protein adsorption on biomaterial surfaces $[2,3,17,18]$. For example, $-\mathrm{CH}_{3}$, polyethylene glycol (PEG) and $\mathrm{OH}$-terminated surfaces bind low levels of fibronectin (FN), which correlates with low cellsurface interactions and were noted to fail to organize the extracellular fibronectin matrix [1].

Another important parameter impacting cellular adhesion during cell seeding is the scaffold conditioning treatment. Briefly, most scaffolds currently used in tissue engineering applications are made from polymeric solutions or suspensions using very well-established manufacturing methods, such as freeze drying lyophilization (FL) [19], solvent casting (SC) and particulate leaching [20], gas foaming [21], rapid-prototyping [22], and electrospinning (ES) [23]. 
Scaffold conditioning is needed to create a cell-friendly environment with $\mathrm{pH}$ ranges close to neutral or adjust mechanical properties of the material to favor cell viability. The effect of scaffold pretreatments on cell attachment and proliferation has been reported for several materials [2432]. For example, 3D poly(L-lactide-co-glycolide) scaffolds treated with $1 \mathrm{M}$ sodium hydroxide have been shown to enhance osteoblast adhesion and differentiation but had impeded proliferation [25]. Such cellular changes are mainly attributed to a nanostructural alteration of the scaffold surface as a result of the $\mathrm{NaOH}$ treatment. Scaffolds prepared from varying ratios of alginate/hydroxyapatite (HAP) via the phase separation technique required pretreatment with a crosslinking agent to slow scaffold dissolution rates [31]. Also, when woven poly(ethylene terephthalate) fabrics were coated with PLGA and an artificial glycopolymer poly [Np-vinylbenzyl-D-lactamide] (PVLA) [30], hepatocyte cells were noted to be spread and in closer contact when compared to uncoated scaffolds, where hepatocytes were rounded, with no noticeable spreading or aggregation. Electrospun PGA fibers, when subjected to acid hydrolysis, have shown an improvement in cell proliferation and in vivo compatibility and in contrast, untreated scaffolds demonstrate low cell proliferation and pronounced inflammation and tissue ingrowth [24]. It is postulated that the surface hydrolysis of ester bonds, as a result of the acid pretreatment step, exposes the carboxylic acid and alcohol groups, thus improving vitronectin binding, hereby increasing cell adhesion.

The general emphasis of our research is to evaluate chitosan scaffolds as substrates for growth and proliferation of chondrocytes. Chitosan (poly 1,4 D-glucosamine), a biocompatible polymer, is a partially deacetylated derivative of chitin and is structurally similar to glycosaminoglycan (GAG). Its structure resemblance to the glycosaminoglycan structure makes it a very suitable candidate for scaffold material [33], as it has been shown to support the expression of ECM proteins [34-38]. However, chitosan requires dissolution in inorganic or organic acids due to its limited solubility in aqueous solutions. Thus postprocessing steps often require the removal of acid remnants by neutralization with sodium hydroxide $(\mathrm{NaOH})[36,39-41]$, sodium bicarbonate $\left(\mathrm{NaHCO}_{3}\right)$ [42], or $\mathrm{NaOH}$-sodium salts mixtures [43, 44]. The underlying hypothesis of this study is that the conditions of neutralization impacts cellular fate; thus in this study chitosan scaffolds that were prepared by freeze drying and lyophilization were subjected to the following pretreatments: sodium hydroxide concentration was varied between $0.1 \mathrm{M}$ and $0.5 \mathrm{M}$ and two different contacting times were studied: 10 minutes and 30 minutes. Subsequently, the attachment of chondrocytes to these scaffolds was analyzed.

\section{Materials and Methods}

2.1. Isolation of Chondrocytes. Intact cartilaginous tissues were obtained from the hip-joint of young calves provided by a local abattoir and were isolated using procedures detailed elsewhere $[45,46]$. Briefly, cartilage slices were incubated with pronase for $1 \mathrm{~h}$ at $37^{\circ} \mathrm{C}$, washed, and incubated in collagenase for $12 \mathrm{~h}$ at $37^{\circ} \mathrm{C}$. Chondrocyte suspension was filtered, spun down and cell pellet was washed and resuspended in DMEM/F12 with $10 \%$ FBS; $100 \mathrm{mM}$ HEPES buffer, $100 \mathrm{U} / \mathrm{mL}$ penicillin, $100 \mu \mathrm{g} / \mathrm{mL}$ streptomycin, $0.29 \mathrm{mg} / \mathrm{mL}$ of L-glutamine and counted in a hemacytometer. Chondrocytes were plated in a $75 \mathrm{~cm}^{2}$ T-flask at a cell density of $10^{4} \mathrm{cells} / \mathrm{cm}^{2}$ in RPMI medium (RPMI 1640 containing $10 \% \mathrm{FBS}, 1 \mathrm{mM}$ sodium pyruvate, $100 \mathrm{mM}$ HEPES buffer, $100 \mathrm{U} / \mathrm{mL}$ penicillin, $100 \mu \mathrm{g} / \mathrm{mL}$ streptomycin, $0.25 \mu \mathrm{g} / \mathrm{mL}$ of amphotericin B, and $0.29 \mathrm{mg} / \mathrm{mL}$ of L-glutamine). Bovine chondrocytes from passage 2 were used in all experiments. Cell culture media and other reagents were obtained from Invitrogen (CA).

\subsection{Preparation of Films and Scaffolds}

2.2.1. Films. A $2 \% \mathrm{w} / \mathrm{v}$ solution of chitosan (degree of deacetylation: $81.7 \%$, molecular weight $=276 \mathrm{kDa}$, Vanson HaloSource, WA) in $1 \%$ acetic acid was freshly prepared. Glass slides $(25 \times 75 \mathrm{~mm})$ or rounded cover slips $(12 \mathrm{~mm}$ diameter) were coated (one side) with a $1 \mathrm{~mL}$ and $0.5 \mathrm{~mL}$ of chitosan solution, respectively, allowed to dry at room temperature overnight, with subsequent heating at $80^{\circ} \mathrm{C}$ for $24 \mathrm{~h}$ to prevent the detachment of the chitosan films. Dried films were then neutralized with $\mathrm{NaOH}$ solutions, copiously rinsed with deionized (DI) water and used immediately.

2.2.2. Scaffolds. Scaffolds were prepared via freezing and lyophilization (FL) using procedures detailed elsewhere [47]. Briefly, a $2 \mathrm{~mL}$ of freshly prepared $2 \% \mathrm{w} / \mathrm{v}$ chitosan solution in $1 \%$ acetic acid was pipetted into each well of a 24 well tissue culture polystyrene plate, frozen at $-20^{\circ} \mathrm{C}$ for $24 \mathrm{~h}$ and then lyophilized at $P<0.1$ torr for $24 \mathrm{~h}$ in a Thermo-Savant Lyophilizer (model no. RVT 4104). Scalpel and biopsy punches were used to cut out scaffolds with the following dimensions: $5 \mathrm{~mm} \times 5 \mathrm{~mm}$. The scaffolds were then neutralized with indicated $\mathrm{NaOH}$ solutions, copiously rinsed with deionized (DI) water, and used immediately.

2.2.3. Neutralization Conditions for Films and Scaffolds. Chitosan films and scaffolds were subjected to sodium hydroxide $(\mathrm{NaOH})$ neutralization. Three different concentrations of $\mathrm{NaOH}$ solutions $(0.1 \mathrm{M}, 0.25 \mathrm{M}$ and $0.5 \mathrm{M})$ and two different contacting times (10 $\mathrm{min}$ and $30 \mathrm{~min}$ ) were used to neutralize the samples.

\subsection{Surface Characterization}

2.3.1. Contact Angle Measurement. Advancing contact angle measurement was performed following sessile drop method with OCA 15, SCA 20, Data Physics Instrument GmbH (Filderstadt, Germany). Water contact angles $(\theta)$ were measured $(1 \mu \mathrm{L}$ with flow rate of $0.1 \mu \mathrm{L} / \mathrm{s})$, and to avoid spreading of the drops and droplet shape variation, contact angle values were recorded within 15-20 seconds after placing the drop. The average contact angle values were collected from at least ten drops on different areas of a test surface and three test surfaces were used for each condition. All measurements 
were conducted in air and at a temperature of $23^{\circ} \mathrm{C}$. In separate experiments, contact angles were measured for chitosan films that were exposed $(16 \mathrm{~h})$ and were not exposed to RPMI medium.

2.3.2. Scanning Electron Microscopy. Morphology of the cells on either coverslips or scaffolds was visualized by SEM. Briefly, samples were rinsed with PBS and cross-linked with $2.5 \%$ glutaldehyde/PBS solution for $30 \mathrm{~min}$. The glutaraldehyde was subsequently rinsed off with PBS and samples were sequentially dehydrated in ethanol solutions (from 20 to $100 \%)$, where samples were incubated for $15 \mathrm{~min}$ in each ethanol concentration. The $100 \%$ ethanol was removed with hexamethyl disilazane (HMDS, Sigma) and finally samples were air-dried. Cast films and scaffolds prepared by FL were coated with gold-palladium $(\mathrm{Au}-\mathrm{Pd})$ and viewed under a scanning electron microscope (SEM, s-3000N, Hitachi, Tokyo, Japan).

2.3.3. Fourier Transform Infrared Spectroscopy (FTIR). FTIR spectra were recorded in the transmittance mode using a Nicolet 20XB spectrometer, in the range of $4000-400 \mathrm{~cm}^{-1}$, with a spectral resolution of $2 \mathrm{~cm}^{-1}$. Chitosan films were removed from the glass slide and subjected to indicated treatments with $\mathrm{NaOH}$, and dried overnight at $40^{\circ} \mathrm{C}$.

2.4. Sodium Dodecyl Sulfate Polyacrylamide Gel Electrophoresis (SDS-PAGE). Chitosan scaffolds $(n=8)$ that were neutralized with indicated concentrations of $\mathrm{NaOH}$ were copiously rinsed with DI water followed by three 10-minute washes with PBS. Scaffolds were then incubated in RPMI media for $24 \mathrm{~h}$ at room temperature. After that, they were copiously rinsed with multiple washes of PBS and surface adsorbed proteins were then eluted with $200 \mu \mathrm{L}$ of $2 \%$ SDS (Invitrogen) for $4 \mathrm{~h}$. The protein concentration in the eluate was measured by the bicinchoninic acid (BCA) method and a volume equivalent to a total protein $(8 \mu \mathrm{g} / \mathrm{well})$ was subjected to SDS-PAGE analysis on a 10\% NuPAGE gel under denaturing conditions.

\subsection{Cell Seeding}

2.5.1. On Films. Chitosan-coated coverslips were placed in 24 well TCP plates and were first disinfected with $70 \%$ ethanol for one hour, rinsed with sterile DI water and PBS, and incubated with RPMI-1640 medium (Gibco, NY) that was supplemented with 10\% FBS (Gibco, NY) and containing $100 \mathrm{U} / \mathrm{mL}$ penicillin, $100 \mu \mathrm{g} / \mathrm{mL}$ streptomycin, $0.25 \mu \mathrm{g} /$ $\mathrm{mL}$ of amphotericin (Gibco, NY) for 24 hours. Bovine chondrocytes were seeded onto the Chitosan-coated coverslips at seeding density of $1 \times 10^{4}$ cells $/ \mathrm{cm}^{2}$ and maintained for $3 \mathrm{~h}$ in $\mathrm{CO}_{2}$ incubator at $37^{\circ} \mathrm{C}, 5 \% \mathrm{CO}_{2}, 95 \%$ humidity followed by addition of RPMI medium. Medium was changed every other day.

2.5.2. On Scaffolds. Cells were seeded on chitosan scaffolds at a cell seeding density of $3.3 \times 10^{4}$ cells/scaffold and maintained in an incubator for $3 \mathrm{~h}$ in $\mathrm{CO}_{2}$ incubator at $37^{\circ} \mathrm{C}, 5 \%$
$\mathrm{CO}_{2}, 95 \%$ humidity, and, subsequently, $8 \mathrm{~mL}$ of medium was added to each well. Typically, 6 to 8 scaffolds were placed per well in a 6-well TCP plate and will be indicated as a test plate. Cells were cultured in RPMI medium. Test plates were placed in a cell culture incubator at $37^{\circ} \mathrm{C}, 95 \%$ humidity and $5 \%$ $\mathrm{CO}_{2}$, and the medium was changed every two days.

2.5.3. Cell Number Estimation. At the end of the culture period, the scaffolds were removed and placed in $1.5 \mathrm{~mL}$ centrifuge tubes ( 3 scaffolds/tube), and $800 \mu \mathrm{L}$ of a $0.5 \%$ trypsin (Gibco, NY) was added. Tubes were then incubated for 15 minutes in the $\mathrm{CO}_{2}$ incubator at $37^{\circ} \mathrm{C}$ with intermittent manual inversion of the tubes. At the completion of the trypsin step, a $0.4 \mathrm{~mL}$ of RPMI medium was added to each tube and the suspension was centrifuged $(100 \times \mathrm{g})$ to obtain a pellet, which was resuspended with RPMI medium and cells were counted with a hemacytometer.

2.6. Cytoskeletal Organization by Immunochemistry. Cells grown on coverslips or chitosan films were fixed in $4 \%$ paraformaldehyde (PFA) in PBS (solution freshly made) for $2 \mathrm{~h}$ at room temperature, blocked and permeated with block/perm solution (BPS: $0.25 \%$ Triton X-100, $10 \mathrm{mg} / \mathrm{mL}$ of bovine serum albumin, $50 \mu \mathrm{L} / \mathrm{mL}$ of normal goat serum in PBS) and incubated with $1: 200$ th dilution of mouse monoclonal antivinculin antibody (Sigma-V9131) in BPS for $12 \mathrm{~h}$, rinsed with PBS supplemented with $0.1 \%$ BSA (rinsing buffer-RB) and incubated with $1: 200$ th dilution of Alexa-488 (Invitrogen A11001) labeled antirabbit polyclonal antibodies for $12 \mathrm{~h}$ at room temperature and copiously rinsed with RB. Subsequently, specimens were labeled with $1: 100$ th dilution of Alexa 633 phalloidin (Invitrogen A22284) and $1: 100$ th dilution of Anti-Vimentin-cy3 (Sigma C9080) in BPS for 12 hours at room temperature and finally rinsed extensively with RB. Counterstaining with $0.05 \mathrm{mg} / \mathrm{mL}$ of DAPI (Inivtrogen-D1306) was performed for 3 minutes prior to mounting with aqueous mounting medium on coverslips. A confocal laser scanning microscope (Olympus FV500 Inverted_Olympus IX 81) was used to obtain the images.

2.7. Statistical Analysis. Student's $t$-test was used for statistical analysis, and statistical differences were declared as $P<$ 0.05 .

\section{Results and Discussion}

In order to make chitosan-based surfaces or scaffolds, it is often necessary to first dissolve chitosan in an acidic solution, and remove the solvent after the scaffold or film preparation step, leaving behind a chitosan acetate material. Thus neutralization steps are undertaken to remove acid remnants, regenerate the $\mathrm{NH}_{2}$ groups on the chitosan, and render the surface hydrophilic and cell compatible. However, the conditions of this neutralization step have not been completely evaluated, leading to variability in the extent of cellular adhesion obtained during the cell-seeding step. Typically, invitro tissue engineering methods rely on good initial cell 
adhesion to yield optimal starting cell densities. Thus our objective was to find optimal regimens of scaffold pretreatment for chitosan-based scaffolds such that reliable starting cell densities, the maximum cell attachment without losing the chondrocyte phenotype can be obtained. Hence, in this paper, chitosan scaffolds or films that were prepared from $2 \%(\mathrm{w} / \mathrm{v})$ solution of chitosan in acetic acid were neutralized with varying concentrations of sodium hydroxide for different incubation times. As 3D scaffolds present technical difficulties (i.e., lack of a flat surface) in surface characterization measurements, chitosan films were used when estimating surface properties.

Figure 1 shows the FTIR spectra of chitosan films that were neutralized with varying concentrations of $\mathrm{NaOH}$, and FTIR spectra of nonneutralized films were included as controls. In the FTIR spectra for nonneutralized films, peaks at $1560 \mathrm{~cm}^{-1}$ and $1400 \mathrm{~cm}^{-1}$ correspond to the asymmetric and symmetric stretching of the carboxylate ion [48], characteristic of the presence of acetate ion in the chitosan acetate salt. These two peaks are replaced by the amide I $(\mathrm{C}=\mathrm{O}$ stretching) and amide $\mathrm{II}(\mathrm{N}-\mathrm{H}$ bending) peaks at $1656 \mathrm{~cm}^{-1}$ and $1546 \mathrm{~cm}^{-1}$, respectively, in the FTIR spectra of neutralized films, denoting the appearance of the amide group characteristic of chitosans not completely deacetylated. The most important feature of the FTIR spectra of neutralized films is the presence of a peak at $1591 \mathrm{~cm}^{-1}$ which corresponds to the $\mathrm{N}-\mathrm{H}$ stretching of the $\mathrm{NH}_{2}$ (amine) group. The removal of the acetate counterion is further confirmed by the appearance of peaks at $1419 \mathrm{~cm}^{-1}$, $1380 \mathrm{~cm}^{-1}$, and $1320 \mathrm{~cm}^{-1}$ corresponding to the $\mathrm{CH}_{2}$ bending, $\mathrm{CH}_{3}$ deformation; symmetric $\mathrm{CH}_{3}$ deformation and $\mathrm{CH}$ bending and $\mathrm{CH}_{2}$ wagging, respectively [49]. From these spectra we were able to conclude that under any of the tested neutralizations conditions, the films were completely neutralized based on the confirmation of the removal of the acetate counterion.

Contact angle measurement was used to assess the polarity of the surfaces after the indicated $\mathrm{NaOH}$ treatments. Measurements were also taken after the surfaces were exposed to medium containing 10\% FBS. Figure 2(a) shows the contact angle of chitosan surfaces that were neutralized with varying concentrations of $\mathrm{NaOH}$ for either 10 or 30 minutes, and subsequently rinsed with DI water and sterile PBS. Contact angle values in the range of $43^{\circ}$ to $65^{\circ}$ were obtained and these values were noted to be lower to that reported elsewhere [41]. For a given treatment time, contact angle values were observed to decrease with an increase in the concentration of $\mathrm{NaOH}$, indicating an increase in the hydrophilic nature of the surface. It was not possible to measure the contact angle of nonneutralized films, as the films resolubilized in aqueous solutions. Figure 2(b) shows the contact angles of chitosan films that were first neutralized with varying concentrations of $\mathrm{NaOH}$, rinsed, and subsequently exposed to FBS supplemented RPMI medium. Contact angle values in the range of $75^{\circ}$ to $95^{\circ}$ were obtained. Films that were neutralized for 30 minutes had lower contact angles when compared to films that were neutralized for 10 minutes implying that longer contacting times between the chitosan acetate surface and sodium hydroxide solution renders more hydrophilic

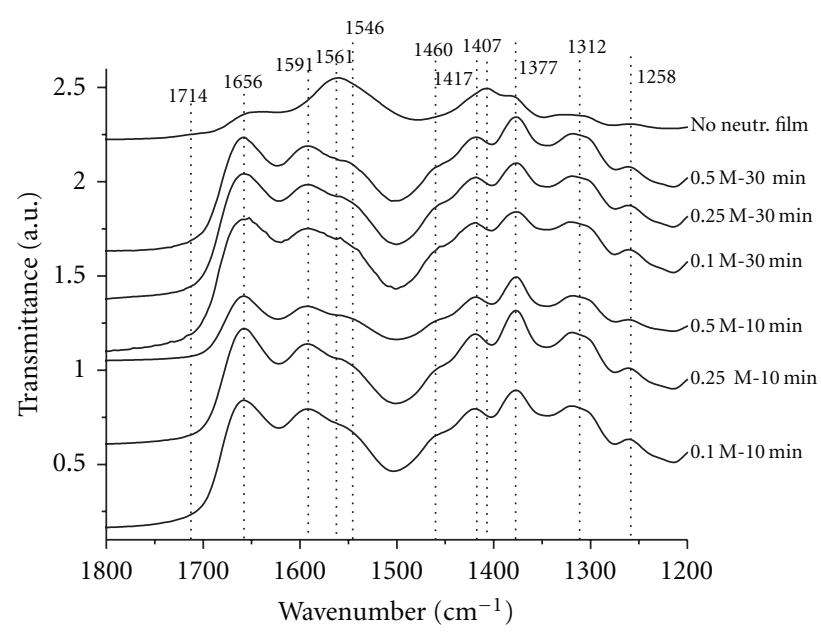

FIGURE 1: FTIR spectra for nonneutralized films showing the peaks at $1560 \mathrm{~cm}^{-1}$ and $1400 \mathrm{~cm}^{-1}$ corresponding to the asymmetric and symmetric carboxylate ion stretching [48] characteristic of the presence of acetate ion in the chitosan acetate salt. FTIR spectra of chitosan films that were neutralized with varying concentrations of $\mathrm{NaOH}$ show the amide I $(\mathrm{C}=\mathrm{O}$ stretching) and amide II $(\mathrm{N}-\mathrm{H}$ bending) peaks at $1656 \mathrm{~cm}^{-1}$ and $1546 \mathrm{~cm}^{-1}$, respectively, characteristic of chitosans not completely deacetylated. Also they show the presence of a peak at $1591 \mathrm{~cm}^{-1}$ which corresponds to the $\mathrm{N}-$ $\mathrm{H}$ stretching of the $\mathrm{NH}_{2}$ (amine) group.

surfaces, comparatively Figure 3(a) shows the SDS-PAGE gel electrophoresis of eluates obtained from chitosan scaffolds that were first neutralized with varying concentration of $\mathrm{NaOH}$, and exposed to media supplemented with FBS. Figure 3(b) shows the semiquantitative evaluation of the bands noted in Figure 3(a) by using ImageJ software. Intensities of the protein bands detected at $55 \mathrm{kDa}, 65 \mathrm{KDa}$, and $75 \mathrm{kDa}$ were further evaluated and compared between different treatment conditions. The observed protein bands at 66$67 \mathrm{kDa}$, and $55 \mathrm{kDa}$ can be assigned to albumin and the heavy chain of IgG (samples were run under reducing conditions) whereas $75 \mathrm{kDa}$ band is more likely to be vitronectin [1]. The total amount of protein adsorbed on scaffolds was observed to decrease with increasing sodium hydroxide concentration.

Surface pretreatments can alter the surface properties and render them hydrophilic or hydrophobic and may also impact the pattern of protein adsorption in an independent manner. Cell and protein adhesion to surfaces has been shown to be modulated by surface chemistry $[2,3,17]$ and additionally, adsorbed proteins may act as intermediates in cell attachment. In this study, treatments with increasing concentration of $\mathrm{NaOH}$ and higher incubation times were noted to increase the hydrophilicity of the surfaces. Interestingly, surfaces preexposed to $10 \%$ FBS in RPMI medium exhibited higher contact angles or increased hydrophobicity when compared to chitosan surfaces that were not exposed to FBS containing medium, possibly due to the nature of the protein adsorbed and also to the conformation status of the proteins on the surface.

An increase in contact angle suggests an increase in the hydrophobic nature of the protein adsorbed surface. 


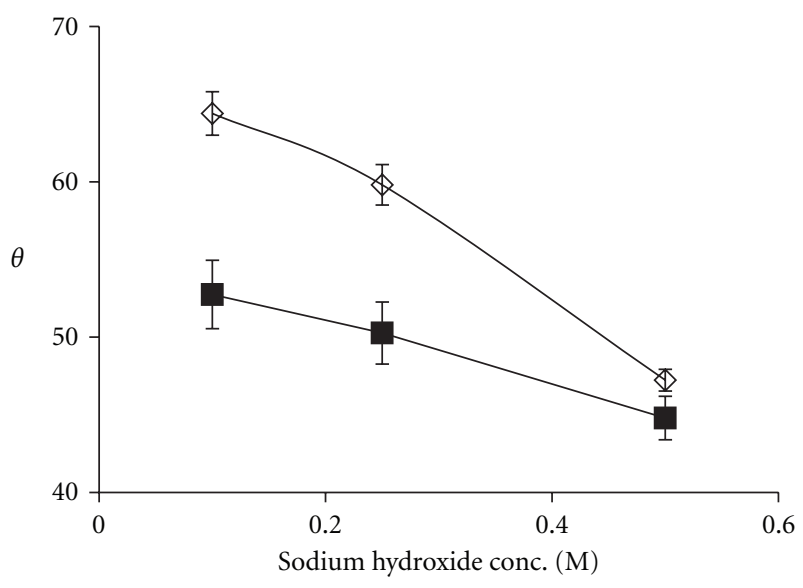

(a)

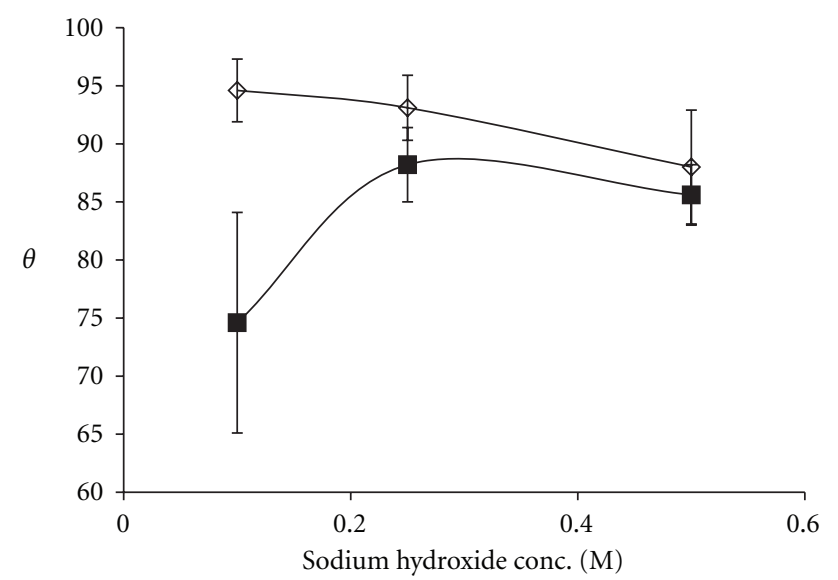

(b)

Figure 2: Contact angle of chitosan surfaces. Water contact angles of the various surfaces prepared were measured. (a) surfaces that were neutralized with varying concentrations of $\mathrm{NaOH}$ for either $10(\diamond)$ or $30(\boldsymbol{\square})$ minutes and rinsed with sterile PBS, (b) contact angle of chitosan films neutralized and exposed to RPMI medium supplemented with $10 \%$ FBS for 16 hours.

The concentration of $\mathrm{NaOH}$ used, and the duration of the neutralization step was observed to influence the total amount of protein adsorbed. Previous investigations have shown that the attachment and spreading of cells are enhanced on moderately wettable surfaces while hydrophobic or nonionic hydrophilic surfaces inhibit interactions with cells. In this work we have used SDS-PAGE electrophoresis to visualize the proteins in the extracts obtained from scaffolds that were preexposed to serum-rich medium. It has been reported elsewhere [50] that serum albumin and immunoglobulins preferentially adsorb onto hydrophobic surfaces while adhesive proteins like FN and VN had higher absorbed amounts on hydrophilic surfaces. The adsorption of fibronectin on tissue culture polystyrene (TCPS) was inhibited by other serum proteins $[51,52]$ while vitronectin was noted to competitively adsorb to the surface in the presence of other plasma proteins. These findings suggested that the attachment of vitronectin to surfaces was more

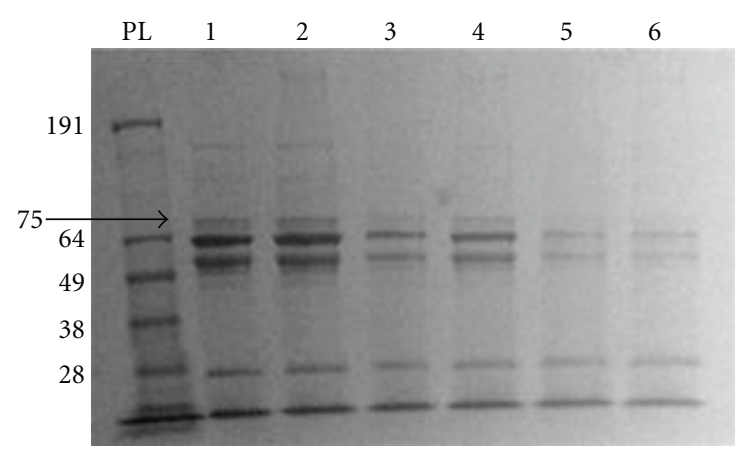

(a)

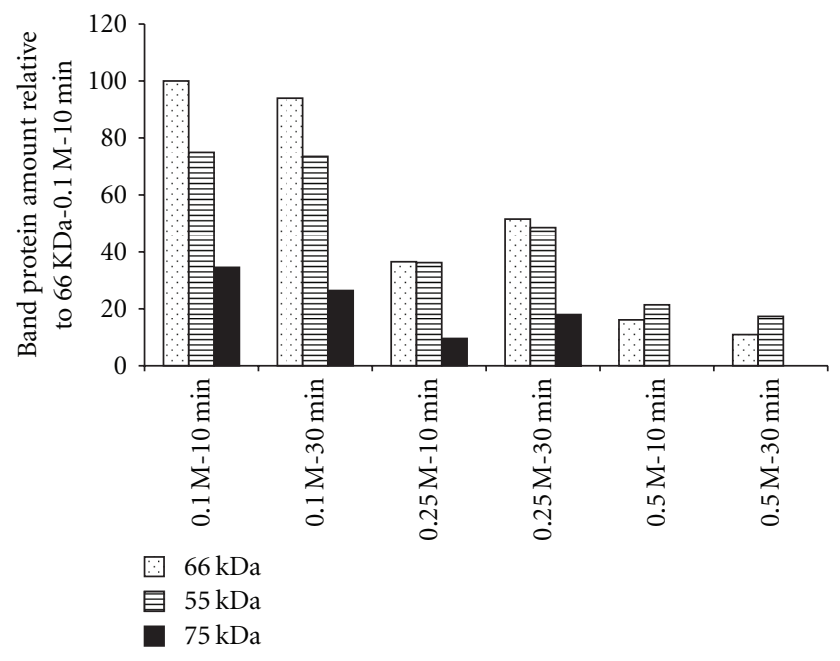

(b)

FIGURE 3: SDS-PAGE analysis of surface adsorbed proteins. Scaffolds that were subjected to the indicated pretreatments were exposed to serum and the surface adsorbed proteins were eluted and analyzed by gel electrophoresis. Typically, 3 to 4 scaffolds were treated as independent experiments. (a) SDS-PAGE of proteins eluates. PL: protein ladder. Lane 1: $0.1 \mathrm{M} \mathrm{NaOH}$ concentration for 10 min., Lane 2: $0.1 \mathrm{M} \mathrm{NaOH}$ concentration for $30 \mathrm{~min}$, Lane 3: $0.25 \mathrm{M} \mathrm{NaOH}$ concentration for $10 \mathrm{~min}$., Lane $4: 0.25 \mathrm{M} \mathrm{NaOH}$ concentration for $30 \mathrm{~min}$., Lane 5: $0.5 \mathrm{M} \mathrm{NaOH}$ concentration for $10 \mathrm{~min}$., and Lane 6: $0.5 \mathrm{M} \mathrm{NaOH}$ concentration for $30 \mathrm{~min}$. (b) Semiquantitative evaluation of the gel image in (a) with ImageJ software.

important than fibronectin for the initial attachment of endothelial cells and fibroblasts [51]. It has also been reported that vitronectin was the main adhesive protein for chondrocyte attachment to TCP and the PEMA/THFMA system in a complete medium [53]. The differential adsorption of vitronectin is also observed, based on the SDS-PAGE gel results shown in Figures 3(a) and 3(b). Figure 3(a) lanes 5 and 6 show the presence of weak $66-55 \mathrm{kDa}$ bands, corresponding to the films neutralized with $0.5 \mathrm{M} \mathrm{NaOH}$ (10 and $30 \mathrm{~min}$ ). The corresponding contact angles for these films before contacting with medium were $47^{\circ}$ and $45^{\circ}$, respectively. Contact angles after contacting with medium were $88^{\circ}-86^{\circ}$, respectively and similarly to Faucheux et al. [1] no vitronectin band $(75 \mathrm{kDa})$ was detected under these 


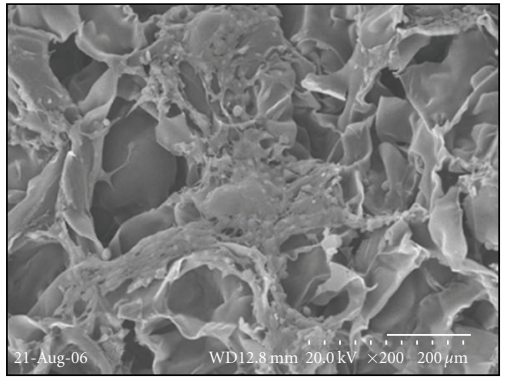

(a)

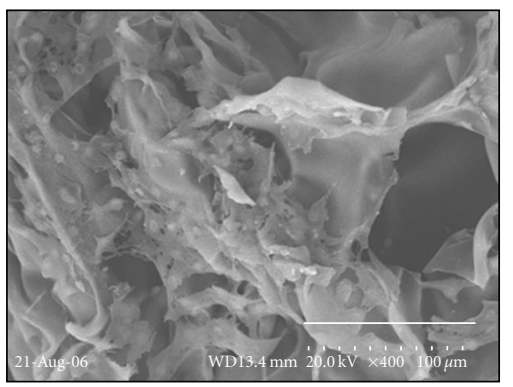

(d)

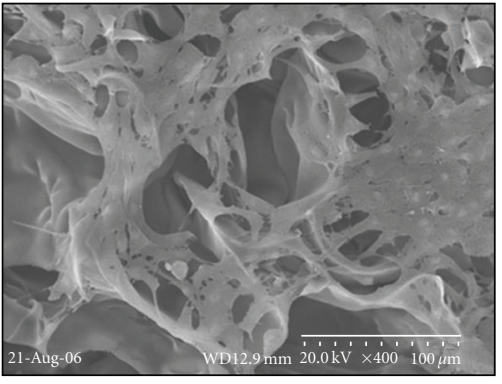

(b)

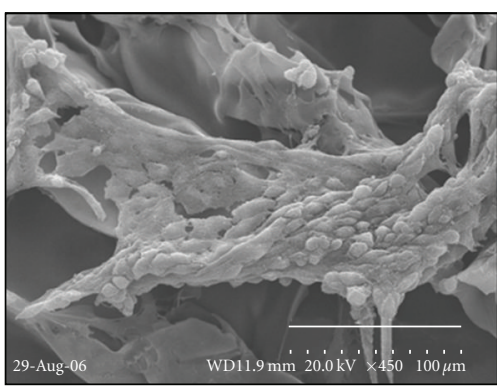

(e)

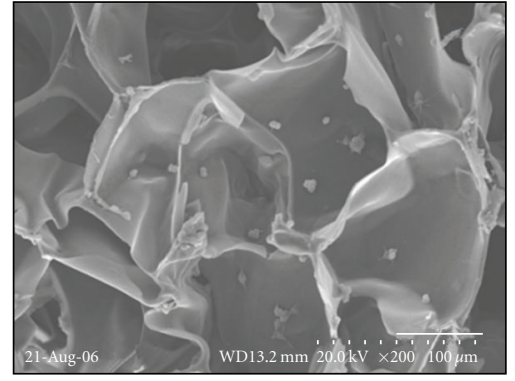

(c)

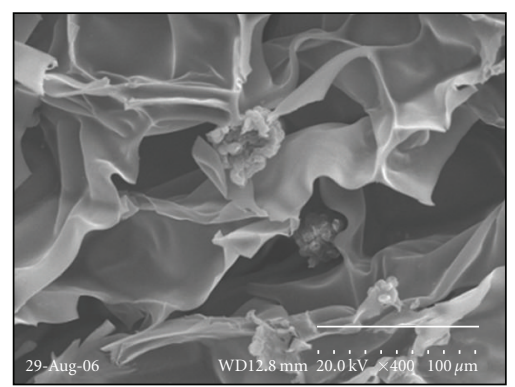

(f)

FIGURE 4: SEM pictures of neutralized 3D scaffolds. (a) Scaffolds neutralized with $0.1 \mathrm{M} \mathrm{NaOH}$ for 10 minutes. (b) Scaffolds neutralized with $0.25 \mathrm{M} \mathrm{NaOH}$ for 10 minutes. (c) Scaffolds neutralized with $0.5 \mathrm{M} \mathrm{NaOH}$ for 10 minutes. (d) Scaffolds neutralized with $0.1 \mathrm{M}$ NaOH for 30 minutes. (e) Scaffolds neutralized with $0.25 \mathrm{M} \mathrm{NaOH}$ for 30 minutes, and (f) Scaffolds neutralized with $0.5 \mathrm{M} \mathrm{NaOH}$ for 30 minutes. Scale bar: $100 \mu \mathrm{m}$.

conditions. Surface wettability has shown to effect protein adsorption, fibronectin was shown to adsorb better on hydrophilic surfaces while albumin was shown to adsorb better on hydrophobic surfaces [54] when exposed to human serum, and similar trends were noted in this study; higher amounts of albumin adsorbed on hydrophobic surfaces compared to more hydrophilic surfaces were noted. It is possible that a balance between surface adsorbed proteins is required for improving cell attachment and proliferation.

Cellular morphology, attachment and proliferation of cells on chitosan surfaces prepared in this study under varying neutralization regimens were evaluated by scanning electron microscopy [55]. Figure 4 shows the representative SEM pictures of adherent cells on neutralized 3D scaffolds. Panel (a) shows cells on scaffolds neutralized with $0.1 \mathrm{M} \mathrm{NaOH}$ for 10 minutes where an elongated cell shape (spindle shape) was observed and a high rate of proliferation was noted. Panel (b) shows cells on scaffolds neutralized with $0.25 \mathrm{M} \mathrm{NaOH}$ for 10 minutes cells also look elongated, proliferation also was high but cell attachment to the scaffold walls was fair, the cells formed a layer and stayed detached from the scaffold. Panel (c) shows cells on scaffolds neutralized with $0.5 \mathrm{M} \mathrm{NaOH}$ for 10 minutes cells look more rounded, proliferation was very low; attachment was poor with few cellular processes, less than 3 extending to the scaffold surface. Panel (d) shows cells on scaffolds neutralized with $0.1 \mathrm{M} \mathrm{NaOH}$ for 30 minutes presented elongated cell shape (spindle shape), proliferation was high, cell attachment was good. Panel (e) shows cells on scaffolds neutralized with $0.25 \mathrm{M} \mathrm{NaOH}$ for 30 minutes, cells look rounded, high proliferation, and good cell attachment to the scaffold. Panel (f) shows cells on scaffolds neutralized with $0.5 \mathrm{M} \mathrm{NaOH}$ for 30 minutes, cells look more rounded and they formed clumps, proliferation was very low. Elongated cells are characteristic of fibroblastic shape or in this case dedifferentiated chondrocytic shape, while rounded shape is characteristic of differentiated chondrocytes. Neutralization with $0.25 \mathrm{M} \mathrm{NaOH}$ for $30 \mathrm{~min}$., $0.5 \mathrm{M}$ for 10 and 30 min rendered rounded cell shape consistent with differentiated chondrocytes, although cells on scaffolds neutralized with $0.5 \mathrm{M} \mathrm{NaOH}$ did not show high proliferations.

Cell density was calculated from 6 to 8 images with the cell counter plug-in available in ImageJ software, where the cell nuclei were counted and their number was divided by the calculated area of the image. Cell proliferation observed in these images is consistent with cell counting in Figure 5. Figure 5 shows the cell counts obtained from scaffolds with indicated pretreatments. The highest cell counts were obtained for scaffolds neutralized with $0.25 \mathrm{M} \mathrm{NaOH}$ for $30 \mathrm{~min}$, followed by scaffolds neutralized with $0.1 \mathrm{M} \mathrm{NaOH}$ for $10 \mathrm{~min}$. Number of cells in scaffolds treated with $0.25 \mathrm{M}$ $\mathrm{NaOH}$ for 30 min were significantly $\left({ }^{*} P<0.005\right)$ higher than number of cells on scaffolds treated with $0.5 \mathrm{M}$ sodium hydroxide for 30 mins. Number of cells in scaffolds treated with $0.1 \mathrm{M}$ sodium hydroxide for 10 minutes is significantly $\left({ }^{*} P<0.01\right)$ higher than number of cells on scaffolds treated with $0.5 \mathrm{M}$ sodium hydroxide, $10 \mathrm{~min}$. In separate experiments, scaffold morphology (in the absence of cells) was determined before and after neutralization and no visible change in scaffold morphology was noted (data not included). 


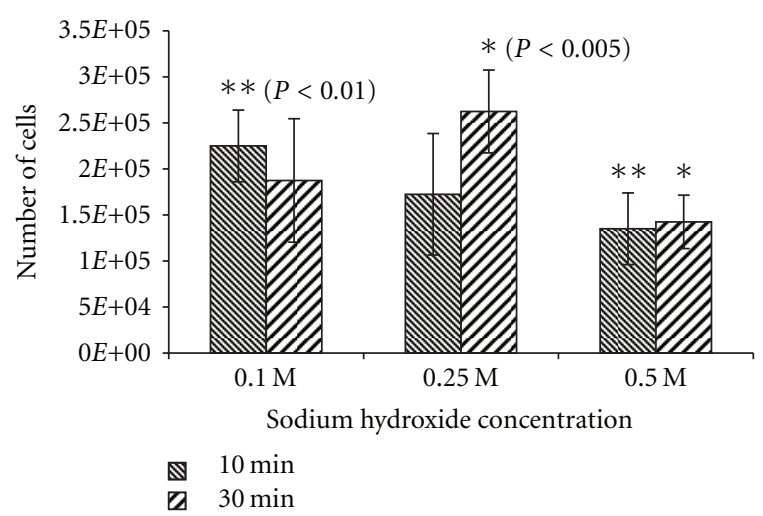

FIGURE 5: Cell counts obtained from scaffolds after 7 days in culture. Cells were released from scaffolds by trypsinization. Significance was considered to be $P<0.05$.

To render the surface cell compatible, acid solubilized chitosan surfaces have been subjected to surface treatments with nitrogen or argon plasma treatment at $20 \mathrm{~W}$ for 10 $40 \mathrm{~min}$. [41]. These modifications were noted to produce an increase in surface roughness as a consequence of the etching process and resulted in improved cell adhesion and proliferation. In this study, the neutralization protocol employed was not observed to impact the gross scaffold morphology; however, we will in a future study characterize the surfaces by atomic force microscopy (AFM).

We have also evaluated the effect of scaffold pretreatments on the cellular morphology and the formation of focal adhesions. The organization of cytoskeletal filamentous actin was examined along with vinculin distribution, and localization of the two. The presence of vinculin is indicative of formation of focal adhesions [56]. Focal adhesions are large protein complexes that act as connectors between the cell and the extracellular matrix. Focal adhesions are important also as signal transduction sites by binding integrins and cytoplasmic proteins as vinculin paxillin, tallin and $\alpha$-actinin. It has been reported that IL- 1 can physically associate to focal adhesions and affect calcium signaling in chondrocytes [57] and can respond to surface roughness [58]. Figure 6 shows the superimposed confocal images for actin-vinculin in cells that were grown on chitosan films and glass slides, respectively. Again, chitosan films were used instead of scaffolds, as they present better surfaces for microscopy. Representative pictures that were obtained upon neutralization for 10-minutes are shown. Panels (a), (b), and (c) show the distribution of actin-vinculin distribution in cells cultured on glass slides. Focal adhesions were apparent by the presence of vinculin, green spots on the cell ends, marked by yellow arrows, on glass slides regardless of $\mathrm{NaOH}$ concentration used and time of incubation. Similar images were obtained for other neutralization times (data not included). Some colocalization of vinculin and actin was evident from the yellow ends in the cells marked as white arrows in the figures. Panel (d) shows the confocal images of cells grown on chitosan films that were neutralized with $0.1 \mathrm{M} \mathrm{NaOH}$ for 10 minutes. Cells were noted to present a well-spread appearance, and the presence of focal adhesions was also evident by the presence of vinculin. Panel (e) shows the confocal images of cells grown on chitosan films that were neutralized with $0.25 \mathrm{M} \mathrm{NaOH}$ for 10 minutes, where the formation of focal adhesions and the presence of cytoskeletal filamentous actin were not noted. Panel (f) shows the confocal images of cells grown on chitosan films that were neutralized with $0.5 \mathrm{M} \mathrm{NaOH}$ for 10 minutes, where the cells look also spread with no detection of filamentous actin or focal adhesion. Panel $(\mathrm{g})$ shows the confocal image of cells grown on chitosan films that were neutralized with $0.1 \mathrm{M}$ $\mathrm{NaOH}$ for 30 minutes cells show spread morphology, no stress actin fibers or focal adhesions; panel (h) shows the confocal image of cells grown on chitosan films that were neutralized with $0.25 \mathrm{M} \mathrm{NaOH}$ for 30 minutes, cells look rounded, high proliferation and good cell attachment to the scaffold, the formation of focal adhesions and the presence of cytoskeletal filamentous actin were not noted; panel (i) shows the confocal image of cells grown on chitosan films that were neutralized with $0.5 \mathrm{M} \mathrm{NaOH}$ for 30 minutes, cells look more rounded, smaller in size and they formed clumps, proliferation was very low. Actin was just detected on the cell membrane and no focal adhesions were detected. The presence of focal adhesions is directly or indirectly related to nature and amount of surface adsorbed and it is postulated that integrin-mediated attachment of cells to surfaces is protein dependent. In our study, only those surface that presented higher amounts of vitronectin $(0.1 \mathrm{M}$ $\mathrm{NaOH}, 10 \mathrm{~min}$ ) developed focal adhesions.

The effect of scaffold pretreatment on the distribution of intermediate filaments (IFs) and cell morphology was also evaluated. IFs also form a mesh that spans from the cell nucleus to the cell membrane but its function is more related to mechanical signal transduction via integrins and also by directly transducing cell deformation to nuclear deformation [59]. Chondrocytes contain vimentin as IF, its assembly is regulated by phosphorylation and it is also in a dynamical equilibrium between polymerized and unpolymerized forms [60], the rounded shape of differentiated chondrocytes is preserved by vimentin [61].

Cytoskeletal intermediate filament vimentin was examined along with actin distribution. Figure 7 shows the superimposed confocal images for actin-vimentin. Representative pictures that were obtained upon neutralization for 10 minutes are shown. Figures 7(a), 7(b), and 7(c) shows actinvimentin distribution of cells grown on glass slides. Vimentin was noted to be present as a very well-spread network of filaments surrounding the nucleus, and expanding throughout the cytoplasm. The distribution of vimentin was not impacted by the concentration of $\mathrm{NaOH}$ used or the time of the neutralization step. Panel (d) shows the confocal image of cells grown on chitosan films that were neutralized with $0.1 \mathrm{M} \mathrm{NaOH}$ for 10 minutes, where cells were noted to be well-spread and the vimentin network was noted to resemble the distribution seen on glass slides; panel (e) shows the confocal image of cells grown on chitosan films that were neutralized with $0.25 \mathrm{M} \mathrm{NaOH}$ for 10 minutes, vimentin filaments were noted to surround the nucleus in a rounded shape but filament distribution around the nucleus 


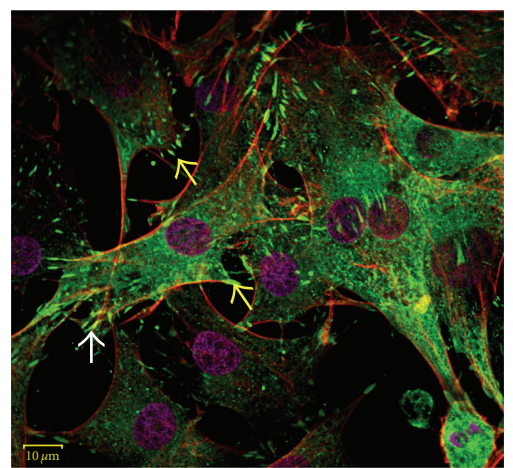

(a)

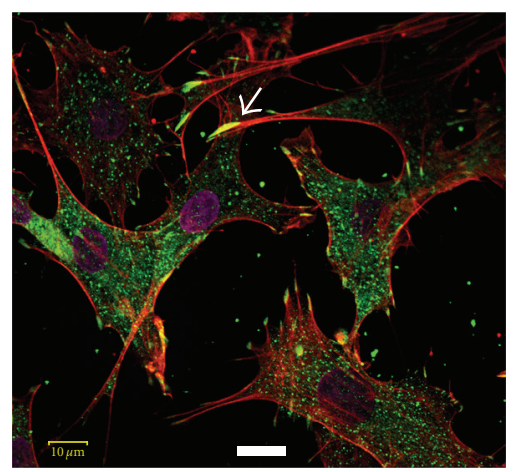

(d)

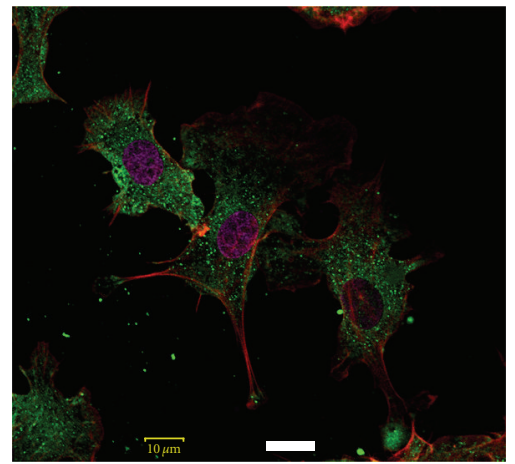

(g)

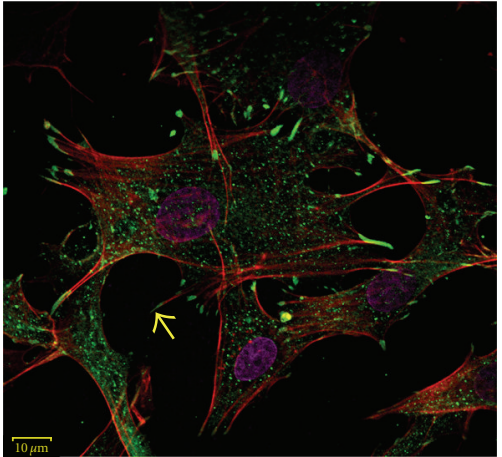

(b)

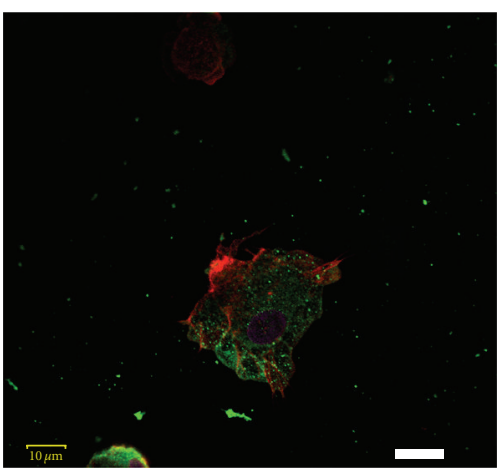

(e)

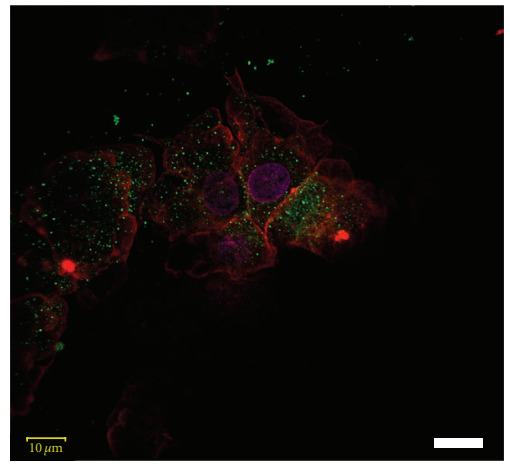

(h)

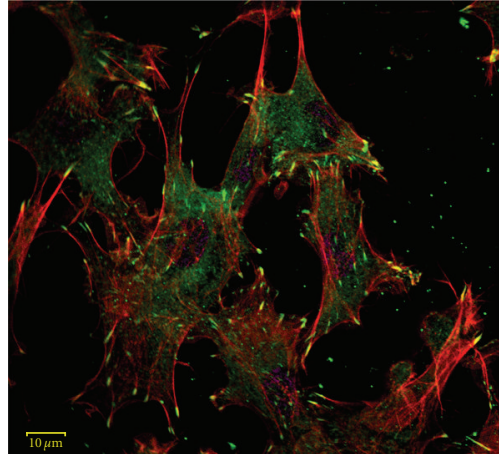

(c)

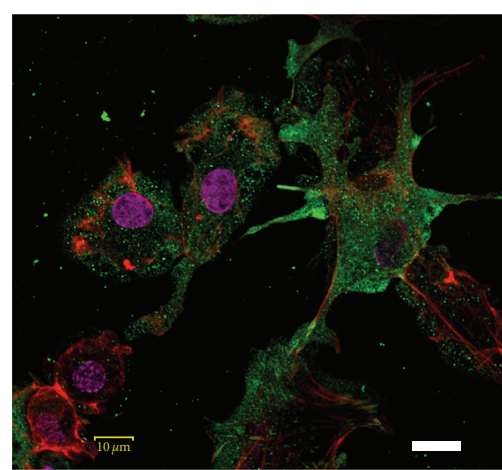

(f)

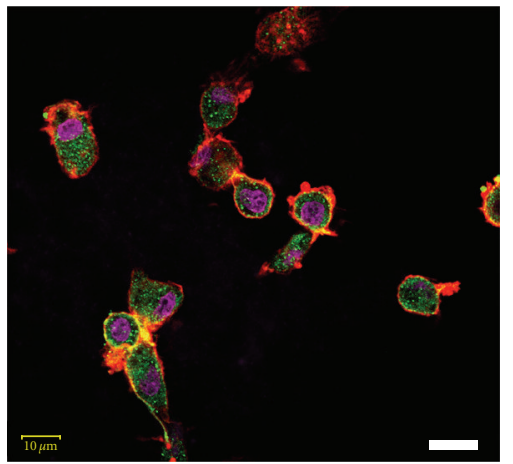

(i)

FIGURE 6: Visualization of actin and vinculin distribution by confocal microscopy. Cells on either glass slides or chitosan films were stained for actin or vinculin as detailed in the methods section. Panels (a), (b), and (c) shows the distribution of actin/vinculin on glass slides. Panels (d), (e), (f), (g), (h), and (i) show the distribution of actin/vinculin on chitosan films. Panel (d) shows chitosan films neutralized with $0.1 \mathrm{M} \mathrm{NaOH}$ for 10 minutes, panel (e) shows chitosan films neutralized with $0.25 \mathrm{M} \mathrm{NaOH}$ for 10 minutes, and panel (f) shows chitosan scaffolds neutralized with $0.5 \mathrm{M} \mathrm{NaOH}$ for 10 minutes, panel (g) shows chitosan films neutralized with $0.1 \mathrm{M} \mathrm{NaOH}$ for 30 minutes, panel (h) shows chitosan films neutralized with $0.25 \mathrm{M} \mathrm{NaOH}$ for 30 minutes, and panel (i) shows chitosan films neutralized with $0.5 \mathrm{M} \mathrm{NaOH}$ for 30 minutes. Similar distributions were noted at different incubation times evaluated. Scale bar: $10 \mu \mathrm{m}$.

was asymmetrical, the cytoskeleton does not posseses actin filaments; panel (f) shows the confocal image of cells grown on chitosan films that were neutralized with $0.5 \mathrm{M} \mathrm{NaOH}$ for 10 minutes where the cell population is a mixture between well-spread cells and rounded shape, vimentin distribution consistent with shape; panel (g) shows the confocal image of cells grown on chitosan films that were neutralized with $0.1 \mathrm{M} \mathrm{NaOH}$ for 30 minutes, where the cells were wellspread and vimentin cytoskeleton was also well-spread; panel (h) shows the confocal image of cells grown on chitosan films that were neutralized with $0.25 \mathrm{M} \mathrm{NaOH}$ for 30 minutes, cells look rounded, high proliferation and good cell attachment to the scaffold vimentin network surrounds the nucleus in a symmetric fashion; panel (i) shows the confocal image of cells grown on chitosan films that were neutralized with $0.5 \mathrm{M} \mathrm{NaOH}$ for 30 minutes, cells look more rounded and they formed clumps, proliferation was very low. Vimentin network encloses the nucleus but the network looks more 


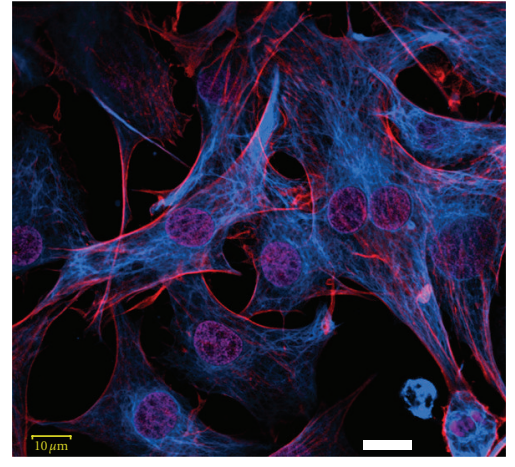

(a)

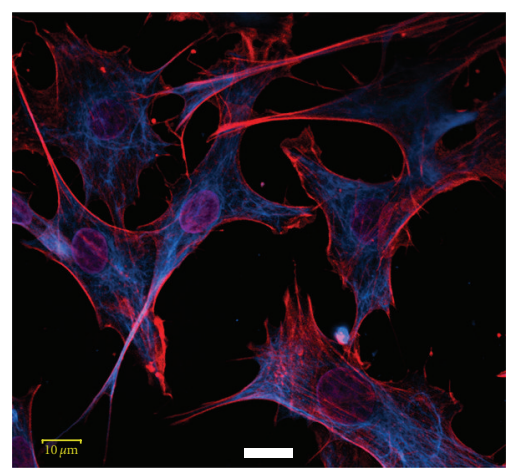

(d)

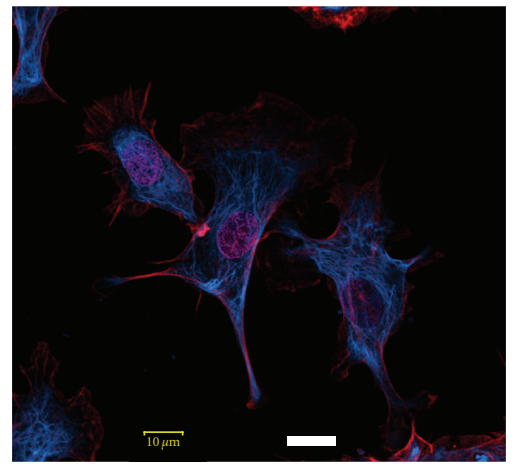

(g)

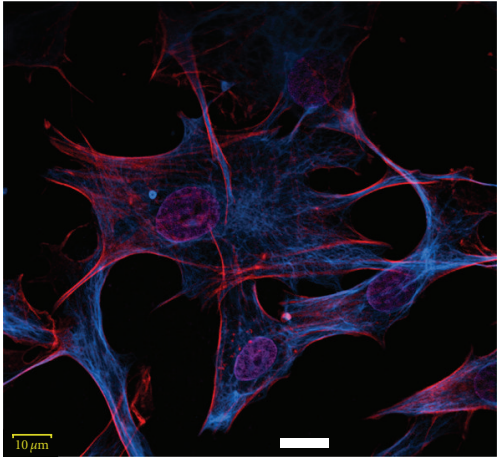

(b)

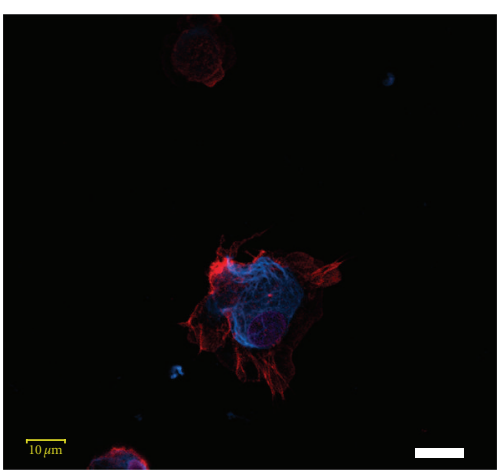

(e)

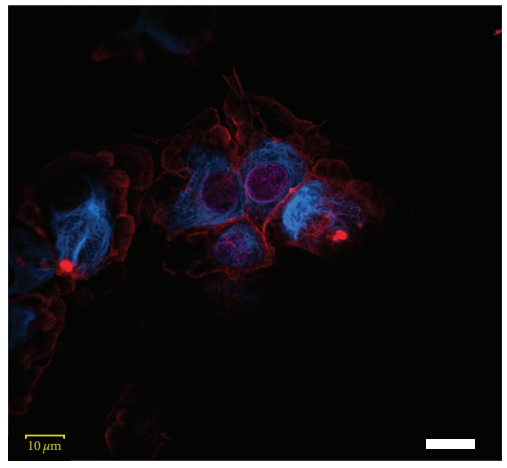

(h)

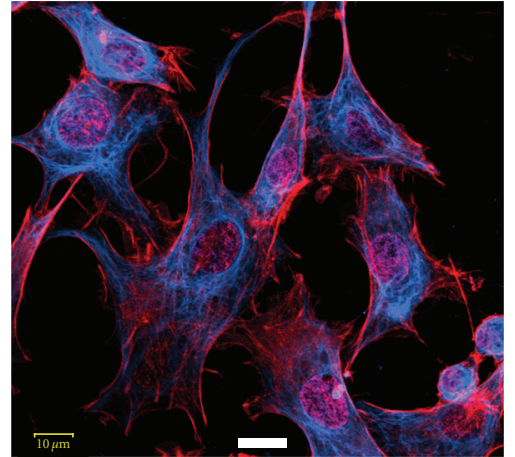

(c)

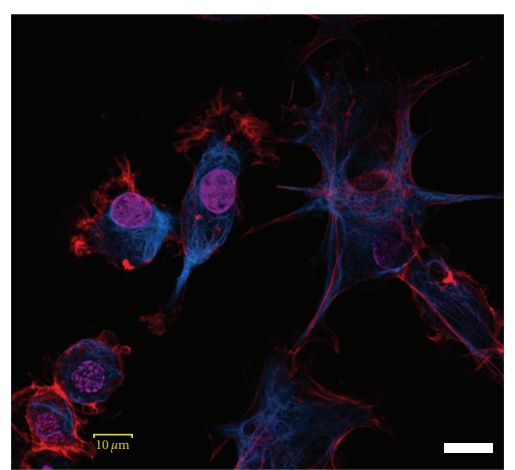

(f)

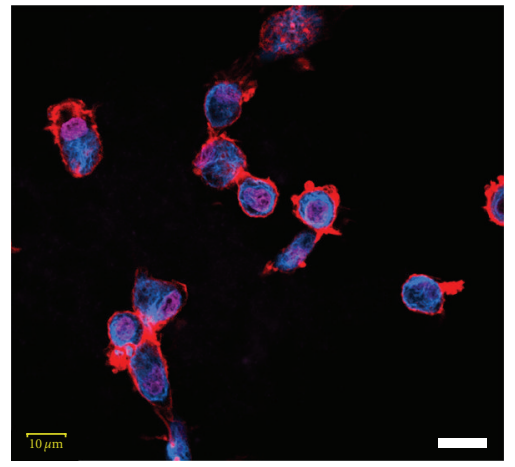

(i)

Figure 7: Visualization of the distribution of actin and vimentin by confocal microscopy. Cells on either glass slides or chitosan films were stained for actin or vimentin as detailed in the methods section. Panels (a), (b), and (c) show the distribution of actin/vimentin on glass slides. Panels (d), (e), (f), (g), (h), and (i) show the distribution of actin/vimentin on chitosan films. Panel (d) shows chitosan films neutralized with $0.1 \mathrm{M} \mathrm{NaOH}$ for 10 minutes, panel-E shows chitosan films neutralized with $0.25 \mathrm{M} \mathrm{NaOH}$ for 10 minutes, and panel (f) shows chitosan scaffolds neutralized with $0.5 \mathrm{M} \mathrm{NaOH}$ for 10 minutes, panel (g) shows chitosan films neutralized with $0.1 \mathrm{M} \mathrm{NaOH}$ for 30 minutes, panel (h) shows chitosan films neutralized with $0.25 \mathrm{M} \mathrm{NaOH}$ for 30 minutes, and panel (i) shows chitosan films neutralized with $0.5 \mathrm{M} \mathrm{NaOH}$ for 30 minutes. Similar distributions were noted at different incubation times evaluated. Scale bar: $10 \mu \mathrm{m}$.

compact due to cell size reduction. In the present study, the distribution of vimentin intermediate filaments was noted to be significantly impacted by the different treatments.

To assess the impact of surface pretreatment employed on cellular morphology, Figures 6 and 7 were quantitatively analyzed by using ImageJ software. The cell shape was estimated by the circularity of the cell, defining circularity as $4 *$ pi $*$ Cell Area $(A) / C$ ll perimeter $(P)$. The shape and size of the nuclei was also determined in a similar manner. The longest distance between two points in a cell, which give us an idea of the longest dimension in a cell, is often measured by the Feret's diameter [62]. A rounded cellular morphology has been reported to be characteristic of a chondrocytic phenotype whereas elongated cellular shapes are reported to more closely resemble a fibroblastic phenotype. Therefore we assign a circularity value of one or close to one to cells typical of chondrocytic phenotype. Figure 8 shows cell circularity, nuclei circularity, cell spread area/nuclei projected area, cell 


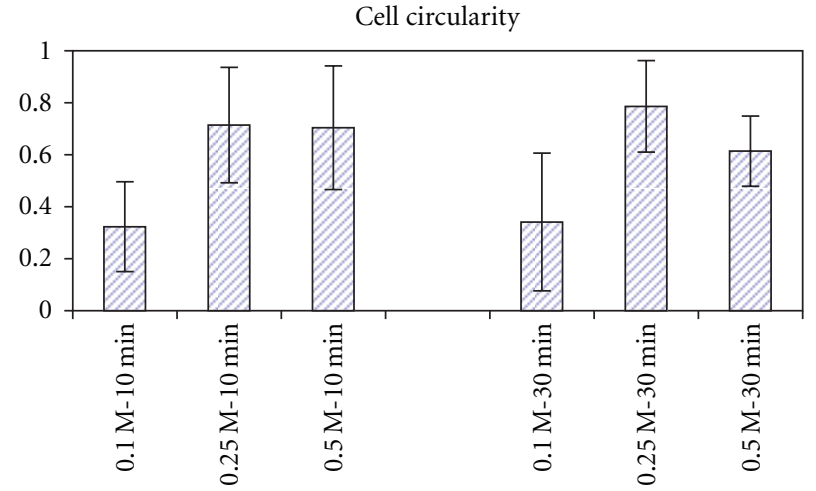

(a)

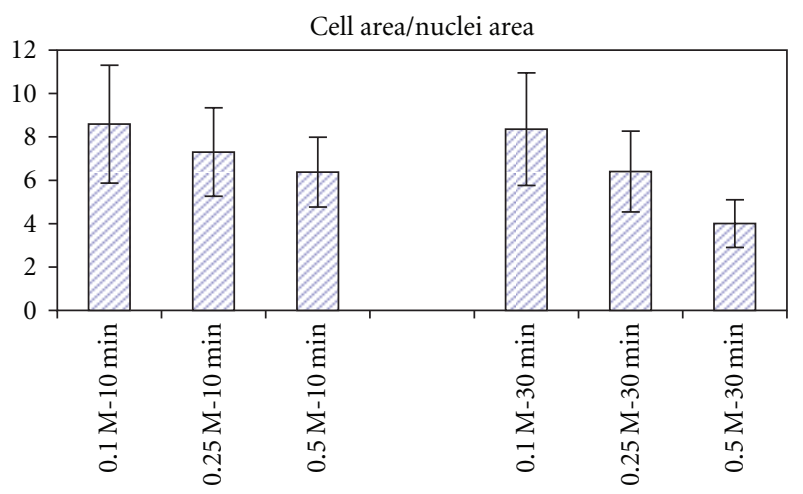

(c)

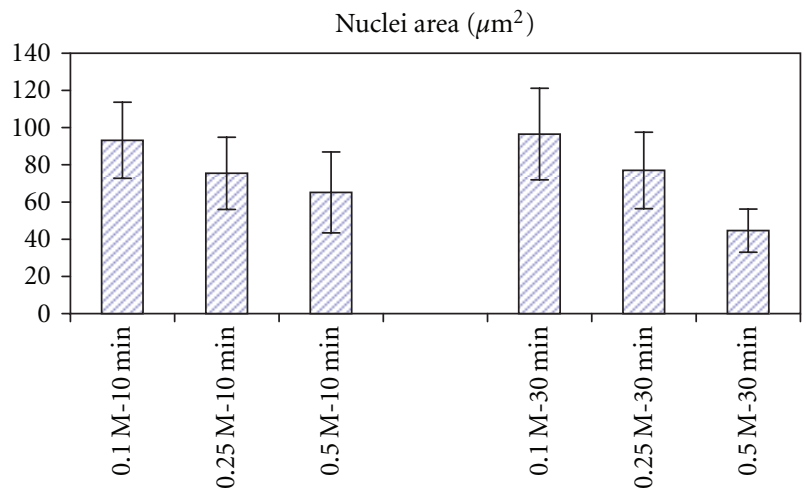

(e)

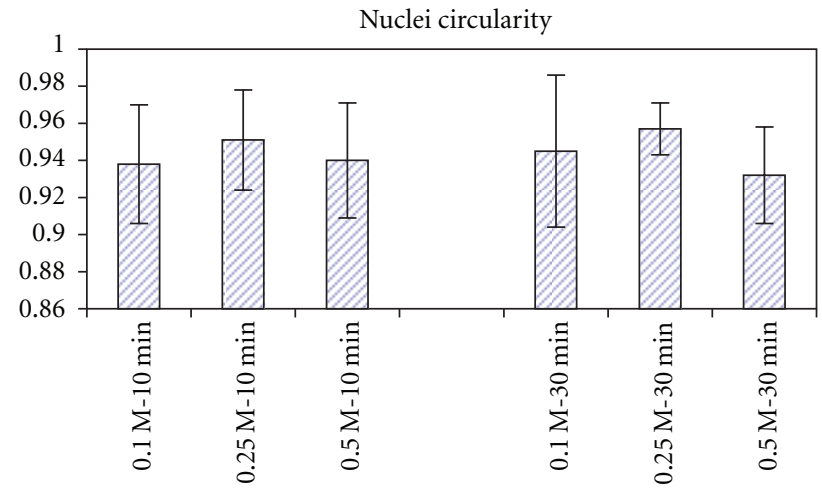

(b)

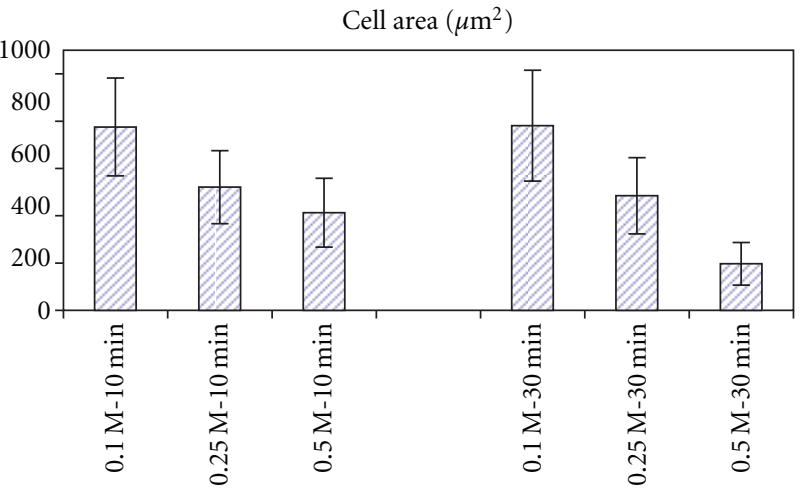

(d)

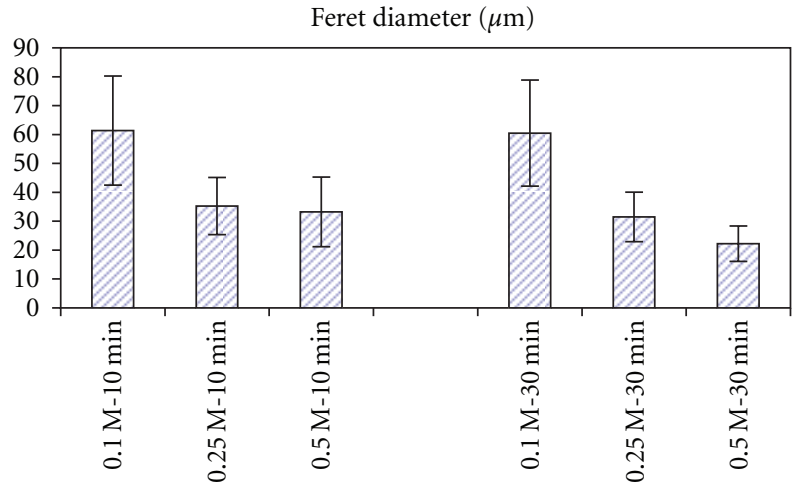

(f)

FIGURE 8: Quantitative analyses of Figure 6. Cell circularity (a), nuclei circularity (b), cell spread area/nuclei projected area (c), cell spread area (d), nuclei projected area (e), and feret diameter (f) for all conditions, the data were extracted from confocal images from 2 different experiments, five sections from each experiment were analyzed. Reported values are mean values \pm S.D.

spread area, nuclei projected area and Feret's diameter for all pretreatment conditions evaluated. The data were extracted from confocal images from 2 different experiments; five sections from each experiment were analyzed. Figure 8(a) shows that cell shape is close to circular shape in samples treated with $0.25 \mathrm{M}$ and $0.5 \mathrm{M}$ sodium hydroxide for $10 \mathrm{~min}$, also for $0.25 \mathrm{M}$ sodium hydroxide for $30 \mathrm{~min}$. with values of $0.8 \pm \mathrm{SD}$, while in cells growing on chitosan surfaces treated with $0.1 \mathrm{M}$ $\mathrm{NaOH}$ for 10 minutes or 30 minutes, cell circularity decrease to $0.3 \pm \mathrm{SD}$ indicating a loss of rounded shape and therefore of chondrocytic morphology. Cell projected area is also reported in Figure 8(d), and a correlation in the reduction of the projected area or cell size with increasing $\mathrm{NaOH}$ concentrations can be noted. Nuclei circularity was higher than 0.9 in all cases as shown in Figure 8(b). Interestingly, the size of the nuclei was noted to change, as determined from the changes in the projected area of the nuclei shown in Figure 8(e), and this trend was noted to mimic or be in agreement with the observed changes in the cell projected area.

In monolayer culture, chondrocytes dedifferentiate into fibroblastic morphology, losing their rounded shape and acquiring a flat and spread shape [63]. Actin in freshly isolated chondrocytes has been found to be focally organized at 
the cell surface resembling a cortical structure. Vimentin in contrast forms a dense network of filament beneath the cell surface and surrounds the nucleus $[61,64]$. Differences in cell spreading were confirmed by the analysis of confocal images. Focal adhesion formation (yellow arrows in panels 6(a) and 6(b)) was evident in cells cultured on glass slides. Vinculin and filamentous actin was observed to colocalize as evidenced by the yellow color formed from the presence of actin (red label) and vinculin (green label) in the same spot at the focal contacts in well-spread cells (see Figure 6, panel (d), white arrow), for cells seeded and cultured on chitosan surfaces that were pretreated with $0.1 \mathrm{M} \mathrm{NaOH}$ for 10 minutes. The vimentin network was widespread and seems to be localized following the actin cytoskeleton shape under these conditions in accordance with observations detailed elsewhere [65], suggesting a direct interaction between the tail domain of vimentin and F-actin. This interaction it was proved to enhance the mechanical properties of mixed actin/vimentin filament networks compared with F-actin or vimentin only networks which would be the cell response to the attachment of the cell through focal contact to the surface, the cell is trying to match stiffness of the surface or balance the forces applied by these focal contact to the cytoskeleton in accordance with Ingber's tensegrity model [66-68]. Blain et al. [64] have reported a distinct shrinkage of chondrocytes associated with vimentin cytoskeleton disruption by acrylamide treatment. A shrinkage of approximately 50\% was seen across their experiments. In our case a decrease of approximately $30 \%$ and 50\% was detected for cells seeded over films pretreated with different sodium hydroxide treatment and 10 minutes of exposure as shown in Figure 8 (d). A decrease of approximately $38 \%$ and $75 \%$ was seen over surfaces exposed to sodium hydroxide for $30 \mathrm{~min}$, see Figure $8(d)$.

Polyelectrolyte behavior of chitosan in acidic solutions is governed by the chelating capacity of amino groups. In acidic solution amino groups are protonated to $\mathrm{NH}^{3+}$ with a $\mathrm{pKa}$ value of 6.1 to 6.4 . Viscosity in the absence of $\mathrm{NaCl}$ increases with protonation of amine group, in contrast when $\mathrm{NaCl}$ is present viscosity is nearly independent of $\mathrm{pH}$ [69]. This polyelectrolyte behavior can be the answer to the differences found in our study. When a chitosan acetate surface is contacted with sodium hydroxide solution, acetate ions tend to associate to its counterion $\left(\mathrm{Na}^{+}\right)$and at the same time $\mathrm{NH}^{3+}$ looses a proton to form a molecule of water, forming a microenvironment on the film surface that assumes the characteristics of a polyelectrolye. The layer in contact with the film present higher viscosities at lower $\mathrm{pH}(0.5 \mathrm{M}$ $\mathrm{NaOH}$ concentration) and lower viscosities at higher $\mathrm{pH}$ $(0.1 \mathrm{M})$ rendering a surface of different characteristics for each value of sodium hydroxide concentration used. With concentrations higher than $0.5 \mathrm{M}$ the effect of high viscosity is more pronounced and can only be alleviated by addition of some sodium salt, a practice that has been applied by some group with success $[43,44]$. In conclusion, pretreatment of chitosan surfaces was noted to impact cell proliferation and differentiation and our studies have helped identify a set of scaffold pretreatment conditions which favor the chondrocytic shape.

\section{References}

[1] N. Faucheux, R. Schweiss, K. Lützow, C. Werner, and T. Groth, "Self-assembled monolayers with different terminating groups as model substrates for cell adhesion studies," Biomaterials, vol. 25, no. 14, pp. 2721-2730, 2004.

[2] A. J. García, "Interfaces to control cell-biomaterial adhesive interactions," Advances in Polymer Science, vol. 203, no. 1, pp. 171-190, 2006.

[3] B. G. Keselowsky, D. M. Collard, and A. J. García, "Surface chemistry modulates fibronectin conformation and directs integrin binding and specificity to control cell adhesion," Journal of Biomedical Materials Research, Part A, vol. 66, no. 2, pp. 247-259, 2003.

[4] K. Webb, V. Hlady, and P. A. Tresco, "Relative importance of surface wettability and charged functional groups on NIH 3T3 fibroblast attachment, spreading, and cytoskeletal organization," Journal of Biomedical Materials Research, vol. 41, no. 3, pp. 422-430, 1998.

[5] K. Webb, V. Hlady, and P. A. Tresco, "Relationships among cell attachment, spreading, cytoskeletal organization, and migration rate for anchorage-dependent cells on model surfaces," Journal of Biomedical Materials Research, vol. 49, no. 3, pp. 362-368, 2000.

[6] Y. Huang, M. Siewe, and S. V. Madihally, "Effect of spatial architecture on cellular colonization," Biotechnology and Bioengineering, vol. 93, no. 1, pp. 64-75, 2006.

[7] V. Vogel and M. Sheetz, "Local force and geometry sensing regulate cell functions," Nature Reviews Molecular Cell Biology, vol. 7, no. 4, pp. 265-275, 2006.

[8] P. Friedl and E. B. Bröcker, "The biology of cell locomotion within three-dimensional extracellular matrix," Cellular and Molecular Life Sciences, vol. 57, no. 1, pp. 41-64, 2000.

[9] C. S. Chen, M. Mrksich, S. Huang, G. M. Whitesides, and D. E. Ingber, "Geometric control of cell life and death," Science, vol. 276, no. 5317, pp. 1425-1428, 1997.

[10] D. W. Hamilton, M. O. Riehle, R. Rappuoli, W. Monaghan, R. Barbucci, and A. S. G. Curtis, "The response of primary articular chondrocytes to micrometric surface topography and sulphated hyaluronic acid-based matrices," Cell Biology International, vol. 29, no. 8, pp. 605-615, 2005.

[11] K. I. T. Kevin Parker, A. M. Y. Lepre Brock, C. Brangwynne et al., "Directional control of lamellipodia extension by constraining cell shape and orienting cell tractional forces," FASEB Journal, vol. 16, no. 10, pp. 1195-1204, 2002.

[12] M. J. Dalby, M. O. Riehle, D. S. Sutherland, H. Agheli, and A. S. G. Curtis, "Fibroblast response to a controlled nanoenvironment produced by colloidal lithography," Journal of Biomedical Materials Research, Part A, vol. 69, no. 2, pp. 314-322, 2004.

[13] C. G. Spiteri, R. M. Pilliar, and R. A. Kandel, "Substrate porosity enhances chondrocyte attachment, spreading, and cartilage tissue formation in vitro," Journal of Biomedical Materials Research, Part A, vol. 78, no. 4, pp. 676-683, 2006.

[14] J. Jagur-Grodzinski, "Polymers for tissue engineering, medical devices, and regenerative medicine. Concise general review of recent studies," Polymers for Advanced Technologies, vol. 17, no. 6, pp. 395-418, 2006.

[15] P. A. Gunatillake, R. Adhikari, and N. Gadegaard, "Biodegradable synthetic polymers for tissue engineering," European Cells and Materials, vol. 5, pp. 1-16, 2003.

[16] X. Liu and P. X. Ma, "Polymeric scaffolds for bone tissue engineering," Annals of Biomedical Engineering, vol. 32, no. 3, pp. 477-486, 2004. 
[17] C. D. McFarland, C. H. Thomas, C. DeFilippis, J. G. Steele, and K. E. Healy, "Protein adsorption and cell attachment to patterned surfaces," Journal of Biomedical Materials Research, vol. 49, no. 2, pp. 200-210, 2000.

[18] C. D. Tidwell, S. I. Ertel, B. D. Ratner, B. J. Tarasevich, S. Atre, and D. L. Allara, "Endothelial cell growth and protein adsorption on terminally functionalized, self-assembled monolayers of alkanethiolates on gold," Langmuir, vol. 13, no. 13, pp. 3404-3413, 1997.

[19] K. Whang, C. H. Thomas, K. E. Healy, and G. Nuber, "A novel method to fabricate bioabsorbable scaffolds," Polymer, vol. 36, no. 4, pp. 837-842, 1995.

[20] A. G. Mikos, A. J. Thorsen, L. A. Czerwonka et al., "Preparation and characterization of poly(l-lactic acid) foams," Polymer, vol. 35, no. 5, pp. 1068-1077, 1994.

[21] L. D. Harris, B. S. Kim, and D. J. Mooney, "Open pore biodegradable matrices formed with gas foaming," Journal of Biomedical Materials Research, vol. 42, no. 3, pp. 396-402, 1998.

[22] S. Yang, K. F. Leong, Z. Du, and C. K. Chua, "The design of scaffolds for use in tissue engineering. Part II. Rapid prototyping techniques," Tissue Engineering, vol. 8, no. 1, pp. 1-11, 2002.

[23] N. Bhattarai, D. Edmondson, O. Veiseh, F. A. Matsen, and M. Zhang, "Electrospun chitosan-based nanofibers and their cellular compatibility," Biomaterials, vol. 26, no. 31, pp. 61766184, 2005.

[24] E. D. Boland, T. A. Telemeco, D. G. Simpson, G. E. Wnek, and G. L. Bowlin, "Utilizing acid pretreatment and electrospinning to improve biocompatibility of poly(glycolic acid) for tissue engineering," Journal of Biomedical Materials Research, Part B, vol. 71, no. 1, pp. 144-152, 2004.

[25] K. H. Carpizo, M. J. Saran, W. Huang et al., "Pretreatment of poly(l-lactide-co-glycolide) scaffolds with sodium hydroxide enhances osteoblastic differentiation and slows proliferation of mouse preosteoblast cells," Plastic and Reconstructive Surgery, vol. 121, no. 2, pp. 424-434, 2008.

[26] M. Cimini, D. R. Boughner, J. A. Ronald, D. E. Johnston, and K. A. Rogers, "Dermal fibroblasts cultured on small intestinal submucosa: conditions for the formation of a neotissue," Journal of Biomedical Materials Research, Part A, vol. 75, no. 4, pp. 895-906, 2005.

[27] D. Guan, Z. Chen, C. Huang, and Y. Lin, "Attachment, proliferation and differentiation of BMSCs on gas-jet/electrospun nHAP/PHB fibrous scaffolds," Applied Surface Science, vol. 255, no. 2, pp. 324-327, 2008.

[28] H. H. Seung, H. K. Yun, S. P. Min et al., "Histological and biomechanical properties of regenerated articular cartilage using chondrogenic bone marrow stromal cells with a PLGA scaffold in vivo," Journal of Biomedical Materials Research, Part A, vol. 87, no. 4, pp. 850-861, 2008.

[29] S.-H. Hsu, T.-B. Huang, S.-C. Chuang, I.-J. Tsai, and D. C. Chen, "Ultrasound preexposure improves endothelial cell binding and retention on biomaterial surfaces," Journal of Biomedical Materials Research, Part B, vol. 76, no. 1, pp. 8592, 2006.

[30] E. Karamuk, J. Mayer, E. Wintermantel, and T. Akaike, "Partially degradable film/fabric composites: textile scaffolds for liver cell culture," Artificial Organs, vol. 23, no. 9, pp. 881-884, 1999.

[31] H.-R. Lin and Y.-J. Yen, "Porous alginate/hydroxyapatite composite scaffolds for bone tissue engineering: preparation, characterization, and in vitro studies," Journal of Biomedical Materials Research, Part B, vol. 71, no. 1, pp. 52-65, 2004.
[32] K. M. Woo, J. Seo, R. Zhang, and P. X. Ma, "Suppression of apoptosis by enhanced protein adsorption on polymer/hydroxyapatite composite scaffolds," Biomaterials, vol. 28, no. 16, pp. 2622-2630, 2007.

[33] V. F. Sechriest, Y. J. Miao, C. Niyibizi et al., "GAG-augmented polysaccharide hydrogel: a novel biocompatible and biodegradable material to support chondrogenesis," Journal of Biomedical Materials Research, vol. 49, no. 4, pp. 534-541, 2000.

[34] V. Hamilton, Y. Yuan, D. A. Rigney et al., "Bone cell attachment and growth on well-characterized chitosan films," Polymer International, vol. 56, no. 5, pp. 641-647, 2007.

[35] V. Hamilton, Y. Yuan, D. A. Rigney et al., "Characterization of chitosan films and effects on fibroblast cell attachment and proliferation," Journal of Materials Science, vol. 17, no. 12, pp. 1373-1381, 2006.

[36] A. Lahiji, A. Sohrabi, D. S. Hungerford, and C. G. Frondoza, "Chitosan supports the expression of extracellular matrix proteins in human osteoblasts and chondrocytes," Journal of Biomedical Materials Research, vol. 51, no. 4, pp. 586-595, 2000.

[37] E. L. Jong, E. K. Seoung, C. K. Ick et al., "Effects of a chitosan scaffold containing TGF- $\beta 1$ encapsulated chitosan microspheres on in vitro chondrocyte culture," Artificial Organs, vol. 28, no. 9, pp. 829-839, 2004.

[38] W. Xia, W. Liu, L. Cui et al., "Tissue engineering of cartilage with the use of chitosan-gelatin complex scaffolds," Journal of Biomedical Materials Research, Part B, vol. 71, no. 2, pp. 373380, 2004

[39] A. G. Karakecili, T. T. Demirtas, C. Satriano, M. Gümüsderelioglu, and G. Marletta, "Evaluation of L929 fibroblast attachment and proliferation on Arg-Gly-Asp-Ser (RGDS)immobilized chitosan in serum-containing/serum-free cultures," Journal of Bioscience and Bioengineering, vol. 104, no. 1, pp. 69-77, 2007.

[40] P. M. López-Pérez, A. P. Marques, R. M. P. D. Silva, I. Pashkuleva, and R. L. Reis, "Effect of chitosan membrane surface modification via plasma induced polymerization on the adhesion of osteoblast-like cells," Journal of Materials Chemistry, vol. 17, no. 38, pp. 4064-4071, 2007.

[41] S. S. Silva, S. M. Luna, M. E. Gomes et al., "Plasma surface modification of chitosan membranes: characterization and preliminary cell response studies," Macromolecular Bioscience, vol. 8, no. 6, pp. 568-576, 2008.

[42] P. Sangsanoh and P. Supaphol, "Stability improvement of electrospun chitosan nanofibrous membranes in neutral or weak basic aqueous solutions," Biomacromolecules, vol. 7, no. 10, pp. 2710-2714, 2006.

[43] M. G. N. Campos, C. R. F. Grosso, G. Cárdenas, and L. H. I. Mei, "Effects of neutralization process on preparation and characterization of chitosan membranes for wound dressing," Macromolecular Symposia, vol. 229, pp. 253-257, 2005.

[44] K. Tuzlakoglu, C. M. Alves, J. F. Mano, and R. L. Reis, "Production and characterization of chitosan fibers and 3-D fiber mesh scaffolds for tissue engineering applications," Macromolecular Bioscience, vol. 4, no. 8, pp. 811-819, 2004.

[45] A. Subramanian and H. Y. Lin, "Crosslinked chitosan: its physical properties and the effects of matrix stiffness on chondrocyte cell morphology and proliferation," Journal of Biomedical Materials Research, Part A, vol. 75, no. 3, pp. 742-753, 2005.

[46] A. Subramanian, D. Vu, G. F. Larsen, and H. Y. Lin, "Preparation and evaluation of the electrospun chitosan/PEO fibers for potential applications in cartilage tissue engineering," Journal of Biomaterials Science, Polymer Edition, vol. 16, no. 7, pp. 861873, 2005. 
[47] C. Nicolini, V. Trefiletti, and B. Cavazza, "Quaternary and quinternary structures of native chromatin DNA in liver nuclei: differential scanning calorimetry," Science, vol. 219, no. 4581, pp. 176-178, 1983.

[48] S. Demarger-Andre and A. Domard, "Chitosan carboxylic acid salts in solution and in the solid state," Carbohydrate Polymers, vol. 23, no. 3, pp. 211-219, 1994.

[49] Y. Dong, C. Xu, J. Wang, M. Wang, Y. Wu, and Y. Ruan, "Determination of degree of substitution for $\mathrm{N}$-acylated chitosan using IR spectra," Science in China, Series B, vol. 44, no. 2, pp. 216-224, 2001.

[50] T. O. Collier, C. R. Jenney, K. M. DeFife, and J. M. Anderson, "Protein adsorption on chemically modified surfaces," Biomedical Sciences Instrumentation, vol. 33, pp. 178-183, 1997.

[51] J. G. Steele, B. A. Dalton, G. Johnson, and P. A. Underwood, "Polystyrene chemistry affects vitronectin activity: an explanation for cell attachment to tissue culture polystyrene but not to unmodified polystyrene," Journal of Biomedical Materials Research, vol. 27, no. 7, pp. 927-940, 1993.

[52] J. G. Steele, G. Johnson, and P. A. Underwood, "Role of serum vitronectin and fibronectin in adhesion of fibroblasts following seeding onto tissue culture polystyrene," Journal of Biomedical Materials Research, vol. 26, no. 7, pp. 861-884, 1992.

[53] R. M. Wyre and S. Downes, "The role of protein adsorption on chondrocyte adhesion to a heterocyclic methacrylate polymer system," Biomaterials, vol. 23, no. 2, pp. 357-364, 2002.

[54] J. Wei, M. Yoshinari, S. Takemoto et al., "Adhesion of mouse fibroblasts on hexamethyldisiloxane surfaces with wide range of wettability," Journal of Biomedical Materials Research, Part $B$, vol. 81, no. 1, pp. 66-75, 2007.

[55] J. Kisiday, M. Jin, B. Kurz et al., "Self-assembling peptide hydrogel fosters chondrocyte extracellular matrix production and cell division: implications for cartilage tissue repair," Proceedings of the National Academy of Sciences of the United States of America, vol. 99, no. 15, pp. 9996-10001, 2002.

[56] K. Burridge and M. Chrzanowska-Wodnicka, "Focal adhesions, contractility, and signaling," Annual Review of Cell and Developmental Biology, vol. 12, pp. 463-519, 1996.

[57] L. Luo, T. Cruz, and C. McCulloch, "Interleukin 1-induced calcium signalling in chondrocytes requires focal adhesions," Biochemical Journal, vol. 324, no. 2, pp. 653-658, 1997.

[58] B. Größner-Schreiber, M. Herzog, J. Hedderich, A. Dück, M. Hannig, and M. Griepentrog, "Focal adhesion contact formation by fibroblasts cultured on surface-modified dental implants: an in vitro study," Clinical Oral Implants Research, vol. 17, no. 6, pp. 736-745, 2006.

[59] E. Langelier, R. Suetterlin, C. D. Hoemann, U. Aebi, and M. D. Buschmann, "The chondrocyte cytoskeleton in mature articular cartilage: structure and distribution of actin, tubulin, and vimentin filaments," Journal of Histochemistry and Cytochemistry, vol. 48, no. 10, pp. 1307-1320, 2000.

[60] M. B. Benjamin, C. W. Archer, and J. R. Ralphs, "Cytoskeleton of cartilage cells," Microscopy Research and Technique, vol. 28, no. 5, pp. 372-377, 1994.

[61] L. A. Durrant, C. W. Archer, M. Benjamin, and J. R. Ralphs, "Organisation of the chondrocyte cytoskeleton and its response to changing mechanical conditions in organ culture," Journal of Anatomy, vol. 194, no. 3, pp. 343-353, 1999.

[62] J. Y. Lim, J. C. Hansen, C. A. Siedlecki, J. Runt, and H. J. Donahue, "Human foetal osteoblastic cell response to polymerdemixed nanotopographic interfaces," Journal of the Royal Society Interface, vol. 2, no. 2, pp. 97-108, 2005.
[63] B. Beekman, N. Verzijl, R. A. Bank, K. von der Mark, and J. M. TeKoppele, "Synthesis of collagen by bovine chondrocytes cultured in alginate; posttranslational modifications and cellmatrix interaction," Experimental Cell Research, vol. 237, no. 1, pp. 135-141, 1997.

[64] E. J. Blain, S. J. Gilbert, A. J. Hayes, and V. C. Duance, "Disassembly of the vimentin cytoskeleton disrupts articular cartilage chondrocyte homeostasis," Matrix Biology, vol. 25, no. 7, pp. 398-408, 2006.

[65] O. Esue, A. A. Carson, Y. Tseng, and D. Wirtz, "A direct interaction between actin and vimentin filaments mediated by the tail domain of vimentin," Journal of Biological Chemistry, vol. 281, no. 41, pp. 30393-30399, 2006.

[66] D. E. Ingber, "Tensegrity-based mechanosensing from macro to micro," Progress in Biophysics and Molecular Biology, vol. 97, no. 2-3, pp. 163-179, 2008.

[67] D. E. Ingber, "Tensegrity I. Cell structure and hierarchical systems biology," Journal of Cell Science, vol. 116, no. 7, pp. 1157-1173, 2003.

[68] D. E. Ingber, "Cellular mechanotransduction: putting all the pieces together again," FASEB Journal, vol. 20, no. 7, pp. 811827, 2006.

[69] J. W. Park and K.-H. Choi, "Acid-Base equilibria and related properties of chitosan," ulletin of Korean Chemical Society, vol. 4, no. 2, pp. 68-72, 1983. 


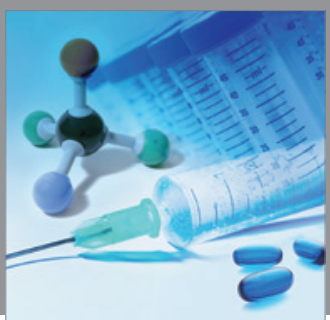

International Journal of

Medicinal Chemistry

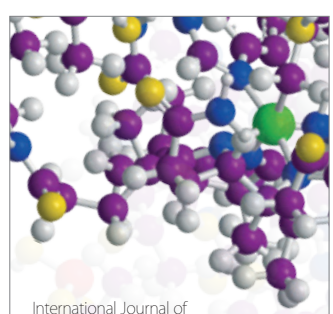

Carbohydrate Chemistry

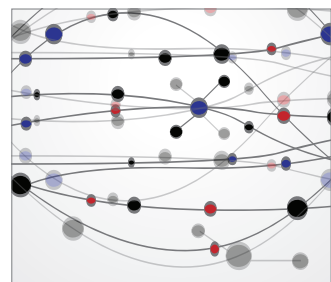

The Scientific World Journal
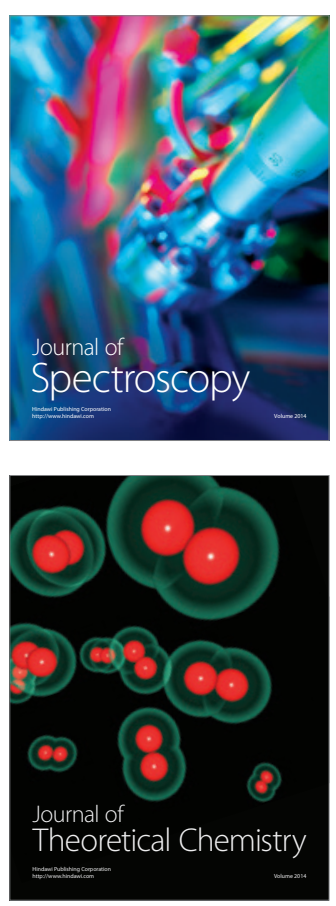
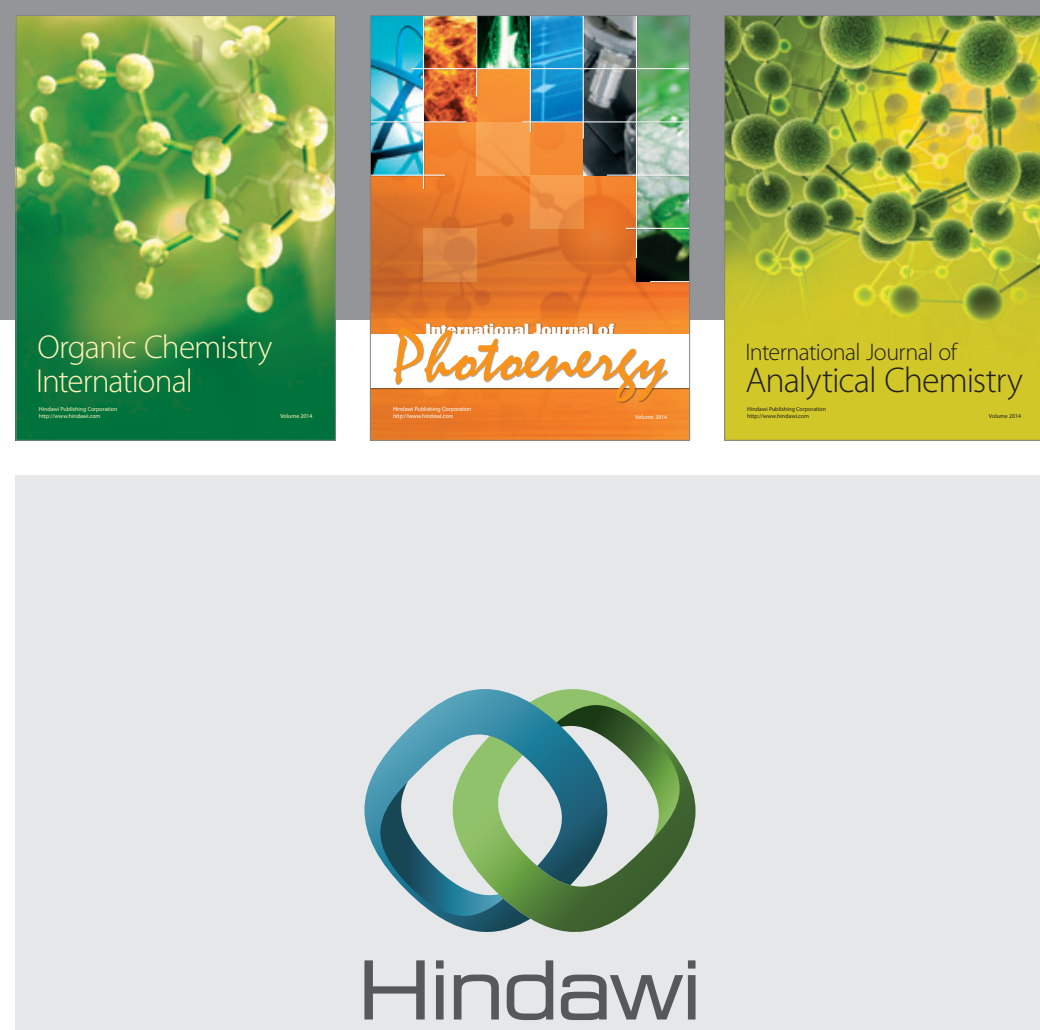

Submit your manuscripts at

http://www.hindawi.com
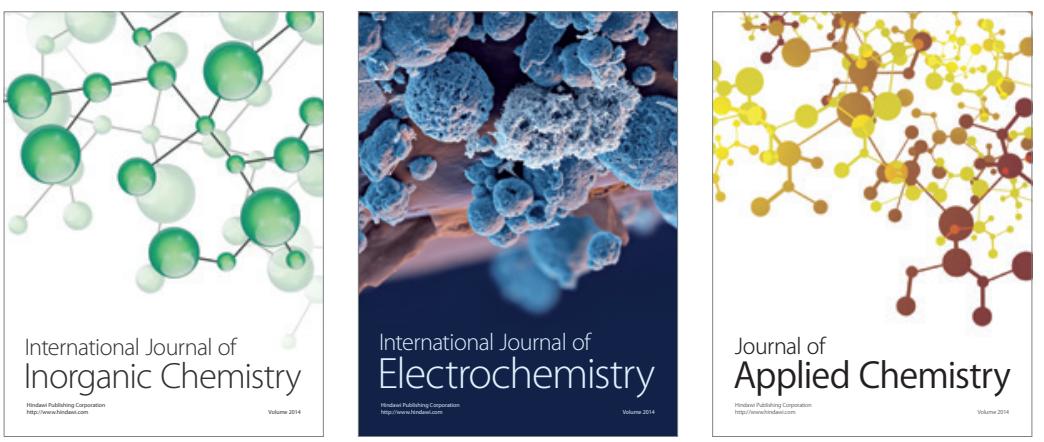

Journal of

Applied Chemistry
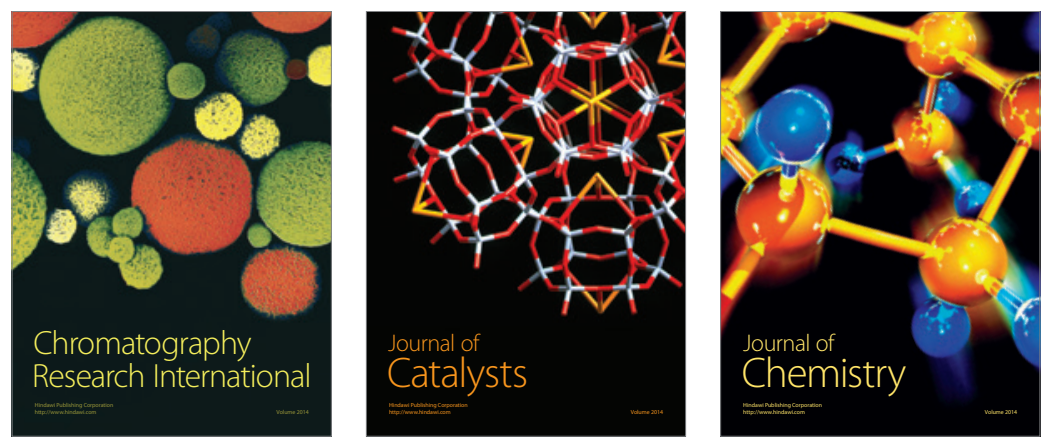
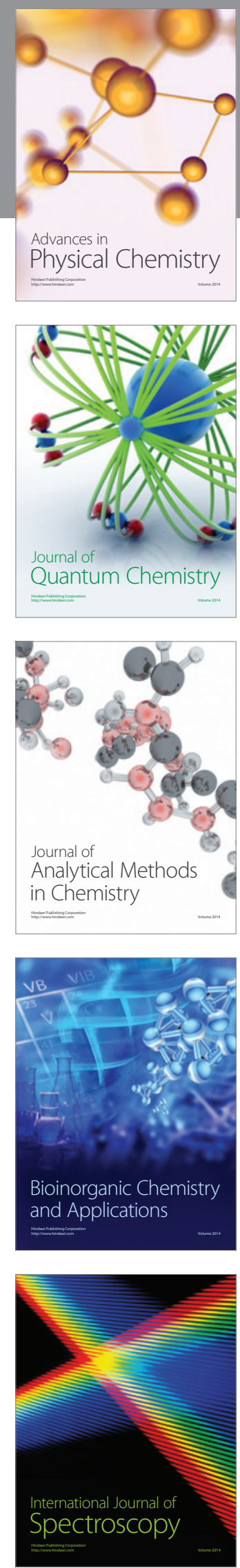